\title{
Dijital Ekonomiye Geçiş Süreci, Ölçümü ve Dijitalleşme Verimlilik İliş̧kisi
}

\section{Transition to the Digital Economy, Its Measurement and the Relationship between Digitalization and Productivity}

\author{
Yasin YILMAZ ${ }^{1}$ (1)
}

\section{Öz}

Teknolojik gelişmeler, dünyada başta ekonomi olmak üzere hayatın her alanında etkisini göstermiştir. Bunun en belirgin örnekleri ekonomik tabanlı devrimler olan, Tarım ve Sanayi Devrimleridir. Günümüzde teknolojik gelişmeler dijitalleşme süreci ile birlikte boyut değiştirmektedir. Teknolojik dönüşümün geçmiş zamanlarda görülmediği kadar hızlı gerçekleşmesi , çalışma hayatında insan - makine iş birliğinin makineler lehine dönmeye başlaması ve sadece mavi yakalı işlerde görülen, makineleşme ve otomasyon üretiminin beyaz yakalı işler de dahil tüm çalışma alanlarına yayııması, otomasyonda kullanılan makinelerin robotlaşması (Cobot) sonucu üretim faktörlerinde emeğin bu yeni teknoloji ürünleriyle ikame edilebilirliği bu dönemin en bariz özellikleri arasında yer almaktadır. Çalışmanın amacı ilk olarak, Türkiye'nin dijitalleşme sürecinde rekabet etmesi gereken ülkelerle kıyaslanmasıdır. Bunun için $A B$ tarafından oluşturulan ve $A B$ ülkelerinin dijitalleşme sürecinde rekabet gücünü ölçmek amacıyla kullandığı Uluslararası Dijital Ekonomi ve Toplum Endeksi (I-DESI) boyutları ve göstergeleri kullanılmıştır. İkinci olarak dijitalleşmenin verimliliğe etkileri literatür taramasıyla araştırılmıştır. Çalışmada; araştırma tasarım yöntemlerinden keşfedici araştırma, veri türlerinden ikincil veriler, kalitatif araştırma yöntemlerinden dokümantasyon yöntemi seçilmiştir. Çalışmanın kapsamını, dijitalleşme sürecinin ekonomik etkileri oluşturmaktadır. Teknolojik gelişmeler hem ürün hem de emek piyasalarında verimliliği arttırmaktadır. Bu nedenle dijitalleşme sürecinin de gerek toplam faktör verimliliğini gerekse işgücü verimliliğini olumlu yönde etkileyeceği düşünülmektedir. Ayrıca I-DESI kapsamında incelemeler yapıldığında, Türkiye'nin dijitalleşme sürecinde henüz yeterli düzeye ulaşamadığı görülmektedir.

Anahtar kelimeler: Dijitalleşme, Dijital ekonomi, I-DESI, Verimlilik, İsgücü verimliliği

JEL Sınıflaması: J01, J21, J23

\section{ABSTRACT}

Technological developments have shown their effects in all areas of life, especially economy in the world. The most obvious

'Dr. Öğr. Üyesi, Bandırma Onyedi Eylül Üniversitesi, Çalışma Ekonomisi ve Endüstri Illişkileri Bölümü, Balıkesir, Türkiye

ORCID: Y.Y. 0000-0002-4046-6580

Sorumlu yazar/Corresponding author: Yasin YILMAZ,

Bandırma Onyedi Eylül Üniversitesi, Çalışma Ekonomisi ve Endüstri Illişkileri Bölümü, Balıkesir, Türkiye

E-posta/E-mail: yasinyilmaz@bandirma.edu.tr

\section{Başvuru/Submitted: 03.05.2021}

Revizyon Talebi/Revision Requested: 08.05.2021

Son Revizyon/Last Revision Received: 09.05.2021

Kabul/Accepted: 10.05.2021

Atıf/Citation: Yilmaz, Y. (2021). Dijital ekonomiye geçiş süreci, ölçümü ve dijitalleşme verimlilik ilişkisi. Istanbul İktisat Dergisi - Istanbul Journal of Economics, 71(1), 283-316. https://doi.org/10.26650/ISTJECON2021-931788 
examples of this are the Agricultural and Industrial Revolutions, which are economically based revolutions. Today, technological developments have changed dimensions with the digitalization process. Today technological transformation have been happening faster than it has been seen in the past, the human-machine cooperation in working life has been starting to turn in favor of machines and the mechanization and automation production, which is seen only in blue-collar jobs, is spread to all work areas including white-collar works, production as a result of robotization of the machines used in new automation (Cobot) The substitution of labor with these new technology products is among the most obvious features of this digitization period. The first aim of the study is to compare Turkey with the countries that should compete in the digitalization process. For this, International Digital Economy and Society Index (I-DESI) dimensions and indicators, which were created by the EU and used to measure the competitiveness of EU countries in the digitalization process, were used. Secondly, the effects of digitalization on productivity have been researched through a literature review. In the study; exploratory research from research design methods, secondary data from data types, and documentation method from qualitative research methods, were used. The scope of the study consists of the economic effects of the digitalization process. Technological developments increase productivity in both product and labor markets. For this reason, it is thought that the digitalization process will positively affect both total factor productivity and labor productivity. In addition, when examinations are made within the scope of I-DESI, it is seen that Turkey has not yet reached a sufficient level in the digitalization process.

Keywords: Digitization, Digital economy, I-DESI, Productivity, Labor productivity

JEL Classification: J01, J21, J23

\section{EXTENDED ABSTRACT}

The effects of the Industrial Revolution first manifested themselves at the economic level, and then paved the way for social, cultural and political transformations through migrations. Similar effects may occur in every transformation process, the severity of which varies depending on the power of the transformation. In this context, a similar link can be established between Industry 4.0 and the first industrial revolution. This is because digitalization and the digital economy affect labor so deeply for the first time, almost 250 years after the first industrial revolution. In addition, the need for manpower in the product market made it helpless for the first time in machine power.

Digitalization directly affects governments, employers and workers. The main reason for this is that the digitalization process reveals new jobs and working styles, and causes transformation in existing jobs. It is estimated that $14 \%$ of G20 countries will be affected by digitalization and switch to automation in the next 15-20 years. In addition, it is thought that the operation of $34 \%$ of the works that cannot be automated at the moment will turn into digital between $50 \%$ and $70 \%$. 
The thought that inequality arising from material and human capital differences in the digitalization process will emerge primarily in wages supports the idea that this problem can be solved with a new taxation system. In addition to taxation, effective use of other transfer policies, social policies and active labor market policies will play an important role in eliminating the above-mentioned inequality. In this context, re-reviewing neo-liberal policies, gaining a national economic perspective, and distributing education programs to the level of lifelong education, not only in educational institutions, but also in all life, will create an opportunity for balance and integration in the society both economically and socially.

In the literature, the opinion that the digitization process will generally affect the workforce productivity positively prevails. However, it is thought that smart machines and robotic automation systems will positively affect not only labor productivity but also total factor productivity.

When digital transformation is considered as a process included in Industry 4.0, it is predicted that it will cause major transformations in working life and professions, similar to the effects of the first industrial revolution. Especially the speed of mechanization and automation will increase production and efficiency. In addition, considering that human beings are not only a biological entity but also a psychosocial entity, the decrease in production efficiency resulting from human and human errors is an expected and observed result. Therefore, it is clear that the machine will be preferred in the production of the human machine. In fact, the automation system that will end the combination of human and machine that occurs with digitalization and production based on this system; It will be an expected result to increase productivity in production by removing the margin of error caused by human values such as fatigue, illness and low morale. For this reason, it is a necessity that some professions are taken from humans and given to machines.

With technological developments, smart machines, machines with artificial intelligence or humanoid machines, which are among the innovations of our age, are included among the production factors and are expected to replace labor from production factors. Despite all this, it is another generally accepted issue that 
manpower is an indispensable input of the product market. The fact that the concept of time between the agricultural revolution and the industrial revolution is similar to the industrial revolution and the digital revolution, increases the anxiety that labor will be harmful from this process. In addition, with the digitalization, the increase in the number of virtual organizations and the transformation of the labor market and the execution of works will necessitate the reorganization of industrial relations. 


\section{Dijitalleşme Süreci ve Ekonomik Etkileri}

Dijitalleşme, "endüstri devriminin ötesinde, insana bağlı ve insansız çalışamayan makinelerin yerini bağımsız düşünebilen, akıllı ve kendi başına çalışabilen makinelerin almasını, sektörlerde üretime katılmasını ve iş hayatında köklü değişikliklere neden olmasını ifade eden genel bir süreçtir" (Y. Yılmaz, 2020b, s. 140). Dijital ekonomi ise "kapsamlı olarak dijital hesaplama teknolojilerine dayanan ekonomi" şeklinde tanımlanmıştır (T.C. Kalkınma Bakanlığı, 2018).

Dijitalleşme; üretimde iş süreçlerinin yenilenmesiyle, verimliliği arttırmak ve çıktı maliyetlerini azaltmak amacıyla, çalışma yaşamında makine-insan simbiyozunu desteklemektedir. Bununla birlikte teknolojik yeniliklerin ve dönüşümlerin çok hızlı ilerlemesine rağmen verimlilikte beklenen artışın, dijitalleşme sürecinde gerçekleşen hıza ayak uyduramadığı görülmektedir. Her değişimin ekonomik ya da sosyal etkilerinin kendini gösterebilmesi için kendi gerçekliğinde bir zaman gerektirdiği gibi dijital dönüşümün bu etkilerinin de zaman içinde daha net görüleceği beklenmektedir. Bunun için öncelikle dijitalleşme sürecinin ülke yönetimi tarafından benimsenmesi, ileri teknolojiye sahip dijital sermaye yoğun firmaların pazar payının arttırılması ve iş modellerinin dijital teknolojilere uyumlu hale getirilmesi, verimlilik hızının dijital dönüşüm hızına adaptasyonunu kolaylaştıracaktır (OECD, 2021, 16, Mart).

Verimlilik ise "dar bir çerçevede, çıktının bir girdiye ya da tüm girdiler toplamına oranıdır. Daha geniş bir tanımla ise, çeşitli mal ve hizmetlerin üretiminde kullanılan emek, sermaye, arazi, malzeme, enerji, bilgi gibi girdilerin, insan ihtiyaçlarının tatminini sağlamak amacıyla etken bir şekilde kullanımıdır" (Y. Yılmaz, 2020a, s. 8). 


\section{Şekil 1. Dijitalleşme ve Teknolojinin Büyüme ve Yaygınlaşma Hızı}
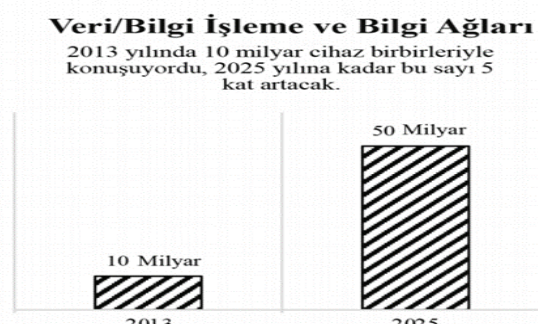

2013

Dijitalden Fizikiye Cevirimi 2020 yılında fabrikalarda çalısan
ndústriyel robot sayısi yakla sık iki kat endüstriyel robot sayısi yakla sik iki kat
artarak 3 milyona çikacak.

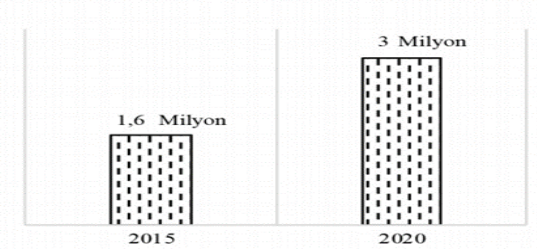

Kaynak: (Gökalp, Gökalp, Çoban \& Eren, 2019).

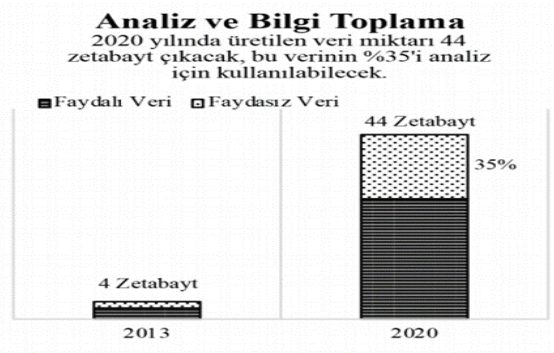

Insanlarm Makinelerle Etkileșimi Sanal ve zenginlestirilmis gerceklik pazarı
2025 yılında 100 milyar dolara eri şebilir.

-Donanm aYazilum

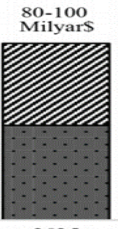

2025

Şekil 1'de; veri işleme ve bilgi ağları ile 2013 yılında 10 milyar cihaz birbirleriyle konuşurken bu sayının 2025 yılında 50 milyar olması öngörülmektedir. 2015 yılında fabrikalarda yaklaşık 1,6 milyon çelik yakalı işçi (robot) çalışan varken bu sayının 2020 yılından yaklaşık iki kat artarak, 3 milyon civarında olması beklenmektedir. 2016 yılında insan makine etkileşiminin (insan-makine simbiyozunun) değeri 3 - 5 milyar dolar iken bu değerin 2025 yılında 80 - 100 milyar dolara çıkacağı tahmin edilmektedir. Netice itibariyle şekil 1'deki veriler bize, dijital dönüşüm hızının zaman içinde katlanarak artacağını göstermektedir. Bu durumun gerçekleşmesi ürün piyasasında, üretim yapısını ve sürecini kökten etkileyerek emek piyasasının da yeniden düzenlenmesini zorunlu kılacaktır.

Dijital ekonomiyi çeşitli yönlerden inceleyen Arthur, dijitalleşme sürecinde dijital çağı üç döneme ayırmaktadır (Arthur, 2021):

1. Dönem; 1970 - 1990 yılları arasında, mikroçip teknolojisinin geliştirilmesi ile ölçme metotlarının sıkça kullanıldığı, mühendislik ve yönetim birimleri başta olmak üzere hesaplamaların bilgisayarlara yaptırılması sürecini kapsamaktadır. 
2. Dönem; 1990 - 2000 yıllarında bilgisayarların artık spesifik alanlardan çıkarak genel kullanıma sunulmasına bağlı olarak, bilgisayar ağlarının ve internetin yaygınlaşması sürecidir

3. Dönem; 2000 'li yıllarda özellikle internet kullanımının yaygınlaşmasının da etkisi ile yazılım sektörünün gelişmesine bağlı, makine ve insan zekâsı karışımı, yapay zekaya sahip akıllı makinelerin ortaya çıkışını içeren ve hâlâ devam etmekte olan bir süreçtir. Üçüncü dönem, makinelerin bir nevi insan gibi düşünebilme kabiliyeti kazanma sürecidir.

Gelişmekte olan ülkelerin çoğunun kullandıkları teknolojileri, ülke dışından temin etmelerinin yanı sıra küresel sermayeye hâkim olan ülkelerden ithal etmektedirler. Bu nedenle gerek gelişmiş gerekse gelişmekte olan ülkelerde dijitalleşme süreci; küreselleşme ve neo liberal politikalara uyumlu bir şekilde hem ticaret ve yatırım olanakları sağlanarak hem de yetenekli insan gücünün işgücü piyasasına girişi kolaylaştırılarak, sağlıklı bir şekilde gerçekleştirilebilecektir.

Dijital dönüşüm süreci; makro düzeyde ülkelerin, mikro düzeyde firmaların gücüne bağlı olarak, yoğun teknolojiye sahip sermaye yatırımlarını zorunlu kılmaktadır. Bu nedenle dijital ekonomiye geçiş sürecinde üretkenliğin sekteye uğramaması adına makine-teknoloji verimliliğinin insan gücüne dayalı verimlilik ile ikame edilmesi gerekmektedir (B. Yılmaz, 2020). Bu bağlamda emeğin yetenek, yetkinlik ve becerilerinin dijital sürece uyumlu hale getirilmesi önem arz etmektedir. Ayrıca işgücüne yapılan beşerî sermaye yatırımları, ileri teknolojiye sahip sermaye yoğun sektörlerin önemli tamamlayıcı olması, verimlilik anlayışının bütüncül bir yaklaşımla sürdürülebilir olmasını da temin etmektedir (Y. Yılmaz, 2020a). Toplumun dijital çağdan ve ekonomiden en üst seviyede yararlanabilmesi için sadece dijital donanım ya da yazılım ürünleri edinmesi yeterli değil ayrıca bu dijital ürünlere uygun kişisel dijital becerilerin de geliştirilmesi gereklidir. Bu dijital beceriler, dijital ürünlerin kullanılmasını sağlayan temel becerilerin yanında dijital ürünleri geliştirmeleri için işgücünü güçlendiren gelişmiş becerilerden oluşmaktadır. 


\section{Tablo 1: 2018 - 2022 Yılları Arasında Emek Piyasasında En Çok Talep Edilecek On Yetkinlik Kıyaslaması}

\begin{tabular}{|c|c|c|}
\hline $\begin{array}{l}\text { Talep Edilen Yetkinlikler } \\
(2018)\end{array}$ & $\begin{array}{c}\text { Talep Edileceği Tahmin Edilen } \\
\text { Yetkinlikler } \\
(2022)\end{array}$ & $\begin{array}{c}\text { Talebinde Azalma Olacağı } \\
\text { Tahmin Edilen Yetkinlikler } \\
\text { (2022) }\end{array}$ \\
\hline Analitik düşünme ve yenilikçilik & Analitik düşünme ve yenilikçilik & $\begin{array}{c}\text { El becerisi, dayanıklılık ve } \\
\text { hassasiyet }\end{array}$ \\
\hline Karmaşık problem çözme & $\begin{array}{c}\text { Aktif öğrenme ve öğrenme } \\
\text { stratejileri }\end{array}$ & $\begin{array}{c}\text { Hafızaya yönelik, sözel, işitsel } \\
\text { ve mekânsal yetenekler }\end{array}$ \\
\hline Eleştirel düşünme ve analiz & $\begin{array}{l}\text { Yaratıcılık, özgünlük ve } \\
\text { inisiyatif }\end{array}$ & $\begin{array}{c}\text { Finansal, maddi kaynakların } \\
\text { yönetimi }\end{array}$ \\
\hline $\begin{array}{l}\text { Aktif öğrenme ve öğrenme } \\
\text { stratejileri }\end{array}$ & $\begin{array}{c}\text { Teknoloji tasarımı ve } \\
\text { programlama }\end{array}$ & Teknoloji kurulumu ve bakımı \\
\hline $\begin{array}{l}\text { Yaratıcılık, özgünlük ve } \\
\text { inisiyatif }\end{array}$ & Eleştirel düşünme ve analiz & $\begin{array}{c}\text { Okuma, yazma, matematik ve } \\
\text { aktif dinleme }\end{array}$ \\
\hline Detaycılık, güvenilirlik & Karmaşık problem çözme & Personel yönetimi \\
\hline Duygusal zekâ & Liderlik ve sosyal etki & $\begin{array}{l}\text { Kalite kontrol ve güvenlik } \\
\text { bilinci }\end{array}$ \\
\hline $\begin{array}{l}\text { Muhakeme, problem çözme } \\
\text { ve kavrayış }\end{array}$ & Duygusal zekâ & $\begin{array}{c}\text { Koordinasyon ve zaman } \\
\text { yönetimi }\end{array}$ \\
\hline Liderlik ve sosyal etki & $\begin{array}{c}\text { Muhakeme, problem çözme } \\
\text { ve kavrayış }\end{array}$ & $\begin{array}{c}\text { Teknoloji kullanımı, izleme ve } \\
\text { kontrol }\end{array}$ \\
\hline $\begin{array}{l}\text { Koordinasyon ve zaman } \\
\text { yönetimi }\end{array}$ & $\begin{array}{l}\text { Sistem analizi ve } \\
\text { değerlendirmesi }\end{array}$ & \\
\hline
\end{tabular}

Kaynak: (Dünya Ekonomik Formu, 2018) verilerinden yararlanılarak hazırlanmıştır.

Dünya Ekonomik Formu'nun "İşlerin Geleceği Raporu'ndan yararlanılarak hazırlanan yukarıdaki tabloda (Tablo 1), 2018 yllında talep edilen ve 2022 yllında da talebinin artması beklenen yetkinlikler arasında; "analitik düşünme ve yenilikçilik", "yaratıcılık, özgünlük ve inisiyatif", "karmaşık problem çözme", "eleştirel düşünme ve analiz", "aktif öğrenme ve öğrenme stratejileri", "yaratıcılık, özgünlük ve inisiyatif", "duygusal zekâ", "muhakeme, problem çözme ve kavrayış", son olarak "liderlik ve sosyal etki" yetkinlikleri yer almaktadır. 2018 yll yetkinlikleri arasında yer alan ve 2022 ylında yer almayacağı tahmin edilen iki yetkinlik; "detaycılık, güvenilirlik", "koordinasyon" ve "zaman yönetimi"dir. 2018 yılı yetkinlikleri arasında yer almadığı halde 2022 yılında talep edileceği tahmin edilen iki yetkinlik ise; sistem analizi ve değerlendirmesi ile teknoloji tasarımı ve programlama yetkinlikleridir (Dünya Ekonomik Formu, 2018).

Dijital çağda sosyo ekonomik olaylar, sadece insan gücü ve emek piyasası 
çerçevesinde değil aynı zamanda diğer üretim faktörleri de dikkate alınarak yorumlanmalıdır. Dijitalleşme süreci gibi sosyo ekonomik etkiye sahip her yeni süreç, tahmin edilmesi güç sonuçları beraberinde getirebildiğinden böyle bilinmezlikler, deneme yanılma yoluna tabi tutulabilmektedir. Bu bağlamda dijitalleşme sürecinin verimliliğe etkisinin pozitif olacağını düşünmek kuvvetli olasllıklar arasında yer alsa da bu etkinin negatif olacağı ya da beklenen düzeyde gerçekleşmeyeceği ihtimalleri de göz ardı edilmemelidir. Çalışma hayatında insanmakine ortak yaşamının (simbiyozunun) sağlıklı bir düzeyde gerçekleşebilmesi için emek-sermaye dengesinin de gözetilmesi önemlidir. Bu nedenle verimliliğin sadece insan ya da sadece makine boyutuyla değil insan ve makine ortaklaşmasını içeren bir yapıda temsili önemli ve gereklidir. Teknoloji alımlarının yüksek maliyeti göz önüne alındığında, dar sermayeye sahip küçük ve orta büyüklükteki işletmeler için dijital dönüşümün ya gerçekleşemeyeceği ya da uzun bir zaman içerisinde gerçekleşebileceği düşünülürken bu negatif etkinin ise kısa süreli çözümünün dijital yetkinliğe sahip insan gücü ile aşılabileceği ifade edilmektedir (Brynjolfsson, Rock \& Syverson, 2017).

Dijitalleşme ve bunun bir sonucu olarak, ileri teknolojik sermaye yatırımlarının ülke genelinde artmasına rağmen verimliliğe bu durumun doğrudan yansımaması ironisi, dijital teknolojilerin büyük ve güçlü firmaların lehine aktarılması ve yayılması ile açıklanabilir. Zira bu firmaların verimlilik artışları yavaşlamayıp, aksine bu firmaların verimliliğinde meydana gelen artışların, küçük firmaların dijital teknolojik eksikliğine bağlı verimlilik azalmalarını da maskelediği görüşü literatürde ifade edilmektedir (Andrews, Criscuolo \& Gal, 2016). Türkiye'de mevcut firmaların büyüklük dağılımları incelendiğinde, KOBi'lerin ${ }^{1}$ oranının ülke içinde \%99.8, KOBI'lerde çalışan oranının \%72.4 ve üretim değerlerinin \%44.1 olduğu görülmektedir. Buna karşın büyük firmaların ülke içindeki oranı \%0.2 ve çalışan

\footnotetext{
1 KOBi'ler "Küçük ve Orta Büyüklükteki İşletmelerin Tanımı, Nitelikleri ve Sınıflandırılması Hakkında Yönetmelik" te aşağıdaki şekilde sınıflandırılmıştır;

a) Mikro işletme: On kişiden az yıllık çalş̧an istihdam eden ve yıllık net satış hasılatı veya mali bilançosundan herhangi biri üç milyon Türk Lirasını așmayan işletmeler.

b) Küçük işletme: Elli kişiden az yıllık çalışan istihdam eden ve yıllık net satış hasılatı veya mali bilançosundan herhangi biri yirmi beş milyon Türk Lirasını aşmayan işletmeler.

c) Orta büyüklükteki işletme: İki yüz elli kişiden az yıllık çalışan istihdam eden ve yıllık net satış hasılatı veya mali bilançosundan herhangi biri yüz yirmi beş milyon Türk Lirasını aşmayan işletmeler.
} 
sayısının \%27.6 olmasına rağmen üretim değerinin \%55.9 olması bu öngörünün haklılığını ispat eder niteliktedir (TÜIK, 2021). Güçlü (büyük) firmalarda ortaya çıkan teknolojiye bağlı verimlilik artışının en önemli nedeni, bu teknolojiyi kullanacak doğru beceri, yetkinlik ve yeteneğe sahip işgücünün, büyük firmalar tarafından tespiti hatta başka işletmelerde bulunan nitelikli insan gücünü kendi bünyelerine transferi noktasındaki başarılı olmalarıdır (Gal \& Nicoletti \& Renault \& Sorbe \& Timiliotis, 2019).

\section{Grafik 1. Türkiye'de büyüklük gruplarına göre temel göstergelerin oransal dağılımı (\%), 2019}

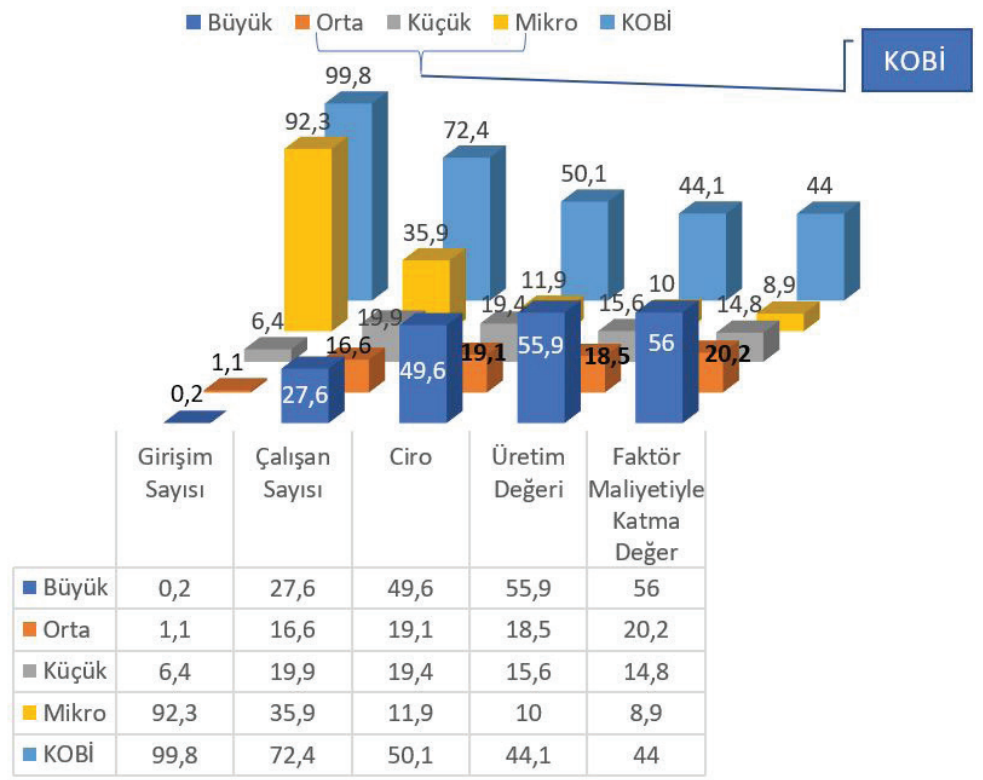

Kaynak: TÜiK. (2021, 16, Mart). Küçük ve Orta Büyüklükteki Girişim İstatistikleri, 2019 verilerinden yararlanılarak hazırlanmıştır.

KOBi'lerin dijital sürece dahil edilmesi ve dijital dönüşümden faydalandırılması, özellikle Türkiye gibi gelişmekte olan ülke ekonomileri için ayrıca önem arz etmektedir. Türkiye'de küçük ve orta büyüklükteki işletmelerin yoğunluğu ve ekonomik etkileri düşünüldüğünde, dijitalleşme sürecine KOBI'lerin erken adaptasyonun makro düzeyde, ekonomiye pozitif etki sağlayacaktır. Dijitalleşme KOBi'ler için teknolojik sermaye yatırımı açısından dezavantajlı bir süreç olarak görülse de bazı fırsatların olduğu gerçeğini de ortadan kaldırmamaktadır. Dijital 
platformların da etkisiyle KOBi'lerin artık küçük birer işletmeler de olsalar, küresel düzeyde ticaret yapabilmeleri, önemli bir güç olabilmeleri fırsatını doğurmuştur. Ayrıca dijital işlerin sanal düzeyde işlevselliğinin hem maliyeti düşürücü hem de nitelikli işgücüne erişimi kolaylaştırıcı etkisi, KOBi'lerin dijital dönüşüm - verimlilik sarmalını güçlendirmektedir. Fakat KOBİlerin uzman insan kaynakları departmanına sahip olmaması durumunda, yetenekli insan gücünün tespiti ve tahlili noktasında yaşanacak eksikliklere bağlı olarak KOBi'ler, dijital yeteneğe ve yeterliliğe sahip işgücünü de istihdam edemeyecekler, bu durumda hem sermaye hem de emek açısından dijitalleşme sürecinde telafisi zor eksikliklerle başa çımak zorunda kalacaklardır.

Dijital dönüşüm her sektörde aynı hızda gerçekleşmemektedir. Bu farklılık genellikle bilgi ve iletişim hizmetlerinin kullanılmasında kendini göstermektedir. Yine yazılımın, tarım ve madencilik gibi sektörlerde çok talep edilmemesi, dijital dönüşümün bu sektörlerde daha geç meydana gelmesine neden olmaktadır (Calvino \& Criscuolo \& Marcolin \& Squicciarini, 2018).

Verimliliği doğrudan etkileyen dijital araç ve uygulamaların, gelişmiş ülkelerde dahi çok yaygın olmaması verimlilik - dijitalleşme arasındaki senkronizasyon uyumsuzluğunun nedenleri arasında yer almaktadır. Dijital dönüşümden tam randıman alınabilmesi için sadece teknolojik yeniliklerin yayılması değil ayrıca bu teknolojiye uyumlu beceriye ve yeteneğe sahip eğitimli işgünün istihdamı, dijital teknoloji - dijital işgücü senkronizasyonunu sağlayan organizasyon yapılanması, iş etütlerinin yeniden yapılarak iş süreçlerinin ve modellerinin baştan kurgulanması, dijitalleşme sürecinin hem yetenekli işgücü istihdamı gibi tamamlayıcı hem de ileri teknolojileri barındıran sermaye yatırımı gibi zorunlu faaliyetlerine bağlıdır (Haskel \& Westlake, 2018). Temel ve tamamlayıcı süreçleri bir bütün olarak gerçekleştiren firmaların dijitalleşme - verimlilik uyumunu yakalayacağı düşünülmektedir (Gal ve ark., 2019).

Verimliliğini umulan düzeyde arttıramayan emek yoğun firmaların, işgücü piyasasının dijital yeterliliğe sahip emeği yetiştirememesi ya da var olan yetkin emeği bu firmaların kendi bünyesine katamaması gibi sebeplere bağlı olarak 
üretim yapısını, emek yoğun işletme anlayışından sermaye yoğun işletme anlayışına doğru güncelleyecekleri düşünülmektedir. Bu çerçevede işletmeler, verimliliklerini özellikle dijital dönüşüm süreciyle uyumlu düzeye getirebileceklerdir (Bükey \& Akgül, 2019, s. 2).

Dijital ekonomiye geçiş sürecinin bütünlük içinde gerçekleşebilmesi için devlet, ekonominin her alanında etkin bir dijital faaliyet süreci yürütmektedir. Dijital sürecin gerçekleşmesi, teknolojinin hem mikro hem de makro düzeyde yaygınlaşmasına bağlıdır. Teknolojik yayılımda; bilgi ve iletişim teknolojilerinin (BIT) yanı sıra teknoloji transferleri, uygulamalı teknoloji ve Ar-Ge merkezleri, teknoloji odaklı iş hizmetleri gibi diğer dijital araçların da uygun bir planlama dahilinde kullanılması önem arz etmektedir. Ayrıca teknoloji yayılımı; dijital medyanın etkili kullanılması başta olmak üzere iş hizmetlerinin dijitalleşmesi, personel eğitimlerinin dijitalleşme sürecine uygun platform ve araçlarla çalışanlara aktarılması ile işgücüne yansıtılabilecektir. Teknolojik yayılımın emek üzerindeki etkisinin daha kısa sürede ortaya çıkması, emek yoğun sektörlerin dijitalleşmeye kısa zamanda uyum sağlaması, emek yoğun işletmelerin sermaye yoğun işletmelere nazaran daha ucuz olması gibi nedenlere bağlı olarak emeğin dijitalleşme sürecine uyum sağlaması, ileri teknolojiye sahip sermaye yoğun sektörlere nazaran öncelikle tercih edilmesine neden olmaktadır (Andrews, Nicoletti \& Timiliotis, 2018).

\section{AB - 2020 I-DESI Ölçümü Çerçevesinde Türkiye'nin Dijitalleşme Sürecinin $A B$ ve $A B$ Dışı Ülkelerle Karşılaştırılması}

Dijital Ekonomi ve Toplum Endeksi (Digital Economy and Society Index (DESI)), ilk defa $A B$ üye ülkelerinin dijital dönüşüm ve dijital kalkınma durumlarının ölçülmesi ve takip edilmesini hedefleyen analitik bir araçtır. Ayrıca DESI, AB üye devletlerinin gerçek bir dijital tek pazar oluşturmaları için öncelikli yatırım gerektiren alanlarının tespiti ve bunların icrasını sağlayacak eylem planlarının oluşturulmasına yardımcı olmayı amaçlamaktadır. 2020-I-DESI ise AB 27 ülkesinin verilerinin yanı sıra $A B$ üyesi olmayan 18 ülkenin² dijitalleşme verilerini

\footnotetext{
${ }^{2}$ AB üyesi olmayan 18 ülke: Türkiye, İsviçre, İsrail, ABD, İzlanda, Birleşik Krallık (BK), Norveç, Japonya, Kanada,
} 
incelemektedir. 2020-I-DESI'nin üç amacı bulunmaktadır. Bunlardan ilki; $A B$ ülkeleri ile üye olmayan 18 ülkeyi kıyaslamak, ikincisi; 27 AB üyesi ülke ile üye olmayan 18 ülke arasında karşılaştırmalı analiz yapmak, üçüncüsü ise yapılan analizler sonucunda $A B$ ülkelerinin belirlenen eksikliklerinin, rekabetçilik düzeylerinin arttırılmasını sağlayarak giderilmesi ve eksiklik olan boyutta karşılaştırma yapılan en iyi değerlendirme puanını alan ülke seviyesine çıkarılmasıdır. Dijital Ekonomi ve Toplum Endeksi (DESI); Bağlantı, İnsan Sermayesi, İnternet Hizmetlerinin Kullanımı, Dijital Teknolojinin Entegrasyonu ve Dijital Kamu Hizmetleri'nden teşekkül 5 boyut ve bu boyutları meydana getiren 24 göstergeden oluşmaktadır (European Commission, 2021, s. 12-15).

Tablo 2: DESI (Dijital Ekonomi ve Toplum Endeksi) Boyut ve Göstergeleri

\begin{tabular}{|c|c|}
\hline Boyutlar & Göstergeler \\
\hline 1. Bağlantı Boyutu & $\begin{array}{l}\text { Sabit Geniş Bant Kapsamı } \\
\text { Sabit Geniş Bant Alım } \\
\text { 4G Kapsamı } \\
\text { Mobil Geniş Bant Alım } \\
\text { Sabit Geniş Bant Hızı } \\
\text { Sabit Geniş Bant Fiyatı }\end{array}$ \\
\hline 2. İnsan Sermayesi Boyutu & $\begin{array}{l}\text { Temel Beceriler } \\
\text { Ileri Düzeyde Beceriler } \\
\text { Temel Yazılım Becerileri } \\
\text { Tam Zamanlı Telekom Çalışanları } \\
\text { - BiT Mezunları }\end{array}$ \\
\hline 3.Internet Hizmetlerinin Kullanım Boyutu & $\begin{array}{l}\text { Internet Kullanıcıları } \\
\text { - Sabit Geniş Bant Trafiği } \\
\text { Video Görüşmeleri } \\
\text { - Sosyal Ağlar } \\
\text { Internet Bankacılığı } \\
\text { - Çevrimiçi Alışveriş }\end{array}$ \\
\hline 4.Dijital Teknolojinin Entegrasyonu Boyutu & $\begin{array}{l}\text { En Son Teknolojilerin Kullanılabilirliği } \\
\text { Firma Düzeyinde Teknoloji Yatırımı } \\
\text { Çevrimicci Satış Yapan KOBi'ler } \\
\text { Güvenli İnternet Sunucuları }\end{array}$ \\
\hline 5. Dijital Kamu Hizmetleri Boyutu & $\begin{array}{l}\text { E Katılım Endeksi } \\
\text { Çevrimiçi Hizmet Tamamlama } \\
\text { Açık Veri }\end{array}$ \\
\hline
\end{tabular}

Kaynak: (European Commission, 2021, s. 45-50) verilerinden yararlanılarak hazırlanmıştır. 
Grafik 2. I-DESI için Normalleştirilmiş ${ }^{3}$ Performans Değerleri ${ }^{4}$

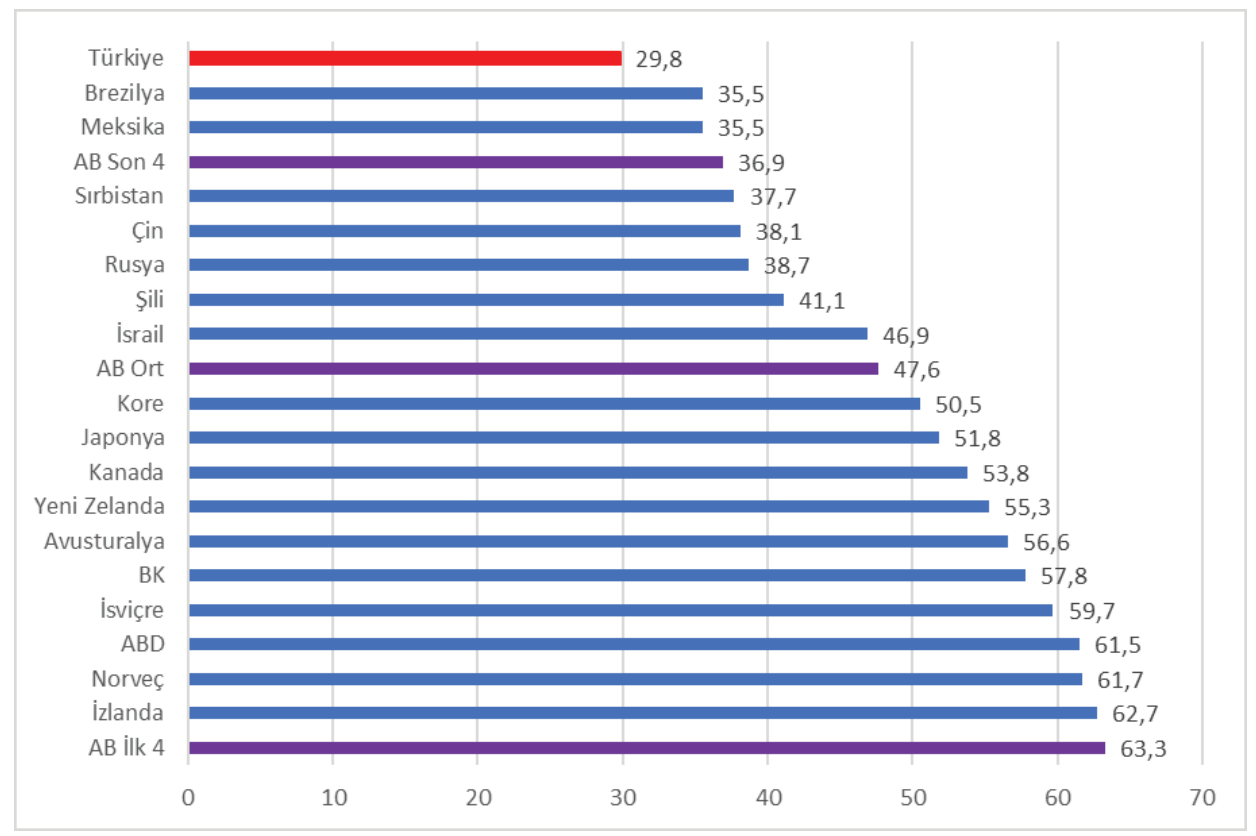

Kaynak: (European Commission, 2021, s. 18) verilerinden yararlanılarak hazırlanmıştır.

2020-Uluslararası Dijital Ekonomi ve Toplum Endeksi (I-DESI) değerinin ölçülebilmesi için belirlenen 5 boyut ve 24 göstergenin genel ölçümü yapıldığında, $A B$ ülkeleri arasında en yüksek I-DESI değerine sahip dört ülkenin ortalaması ( $A B$ İlk 4) 63.3 ile birinci sırada yer almaktadır. İzlanda 62.7, Norveç 61.7, ABD 61.5 ve İsviçre 59.7 değerleri ile ilk beş sırayı oluşturmaktadır. I-DESI puanı en düşük ülke 29.8 ile Türkiye'dir. Brezilya, Meksika, AB ülkeleri arasında en düşük I-DESI değerine sahip dört ülkenin ortalaması ( $A B$ Son 4) ve Sırbistan, I-DESI değerleri en düşük beş ülkedir. I - DESI ölçümlerinde $A B$ ülkelerinin ortalama değerinin ( $A B$ ort), $A B$ üyesi olmayan on sekiz ülkenin onundan sonra gelmesinin, $27 A B$ ülkesinin dijitalleşme sürecinde önemli bir mesafe kat ettiğini göstermektedir. Ayrıca $A B$ ülkeleri arasında üç G7 ülkesinin (Fransa, Almanya ve İtalya) olması, I-DESI

\footnotetext{
${ }^{3}$ Veri Normalleştirme için bakınız, European Commission, 2021, s. 36, 37, 51-57.

${ }^{4}$ Grafiklerde yer alan ülke isimlerinden BK, Birleşik Krallık'ı; Kore ise Güney Kore Cumhuriyetini temsil etmektedir.
} 
değerlerinin, $A B$ ülkelerinin ilk 4 ve ortalama değerlerini pozitif yönde etkileneceğini düşündürmektedir. Türkiye'nin I-DESI değerinin son sırada yer alması; özellikle işletmeler arasında KOBİ oranının \%99.8 gibi yüksek bir oranda olması, KOBi'lerin dijitalleşme sürecini karşılayabilecek yeterli sermayeye sahip olamamaları, beşerî sermayenin de dijitalleşme sürecine yetenek, beceri ve yetkinlik anlamında yeterli düzeyde katılamaması gibi nedenlere bağlanabilir.

\section{Grafik 3. Bağlantı Boyutu İçin Normalleştirilmiş Ülke Değerleri (2018)}

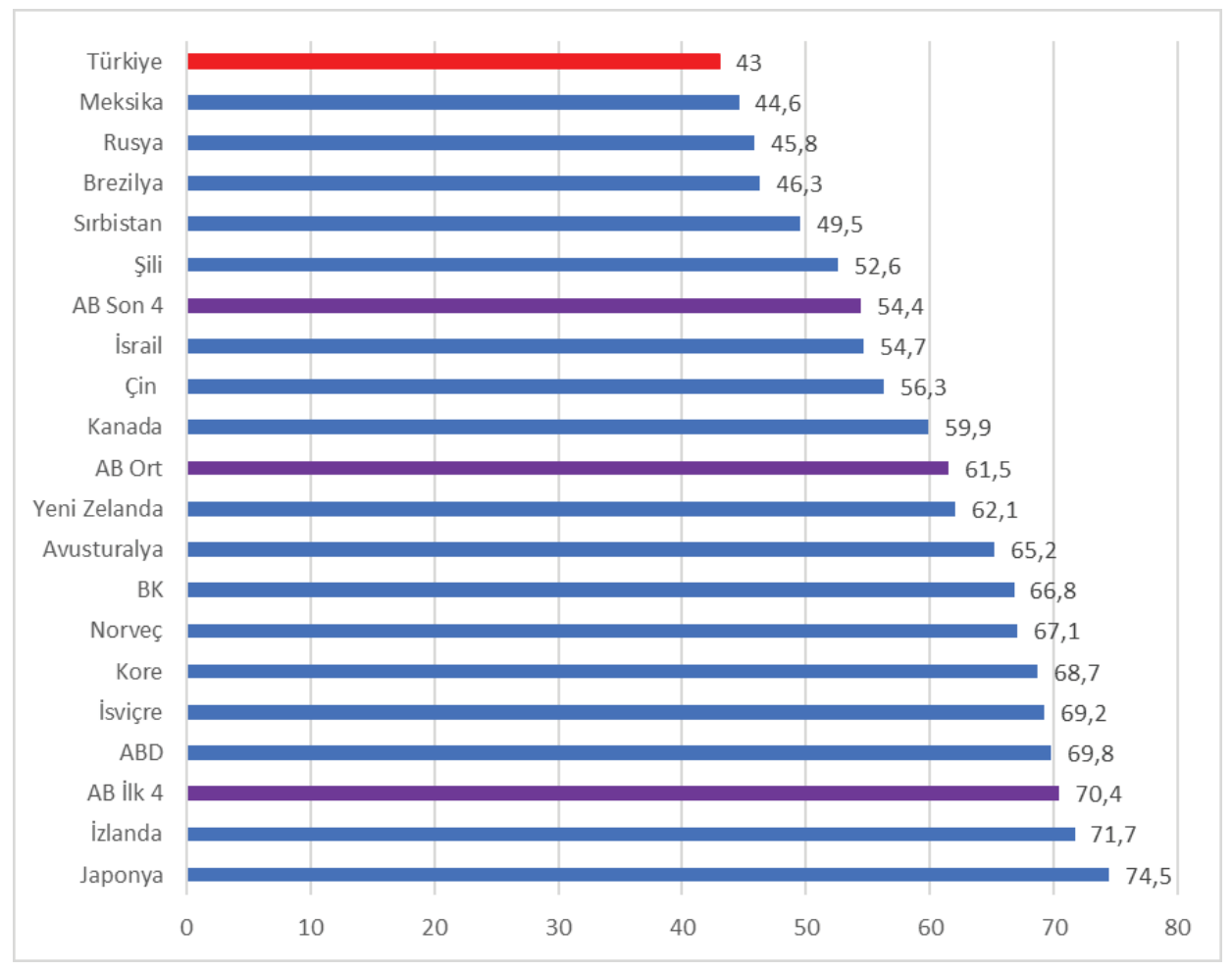

Kaynak: (European Commission, 2021, s. 20) verilerinden yararlanılarak hazırlanmıştır.

Bağlantı Boyutu; dijital ürünlerin kullanılmasının ve tüketilmesinin mümkün hale getirilmesi için dijital alt yapı yatırımının hangi derecede yapıldığını gösteren bir boyuttur. Bu boyut aynı zamanda bireylerin; temel ve gelişmiş dijital beceriler kazanmasında, temel dijital ürün ihtiyaçlarının karşılanmasını ve ülkelerin dijital altyapı yatırımlarını da göstermektedir (European Commission, 2021, s. 20, 21, 35, 45, 46 ). 
Geniş bant altyapısının konuşlandırılmasını ve kalitesini ortaya koyan ve sabit geniş bant kapsamı, sabit geniş bant alım, 4G kapsamı, mobil geniş bant alım, sabit geniş bant hızı, sabit geniş bant fiyatı göstergelerinin ortalama hesaplamasıyla bulunan Bağlantı Boyutu değeri, Grafik 3 incelendiğinde \%74.5 ile en yüksek değeri Japonya almaktadır. Japonya'yı sırasıyla İzlanda, AB Illk 4, ABD ve İsviçre izlemektedir. Bu değerin en düşük olduğu son 5 ülke ise Türkiye, Meksika, Rusya, Brezilya ve Sırbistan'dır.

\section{Grafik 4. Beşerî Sermaye Boyutu İçin Normalleştirilmiş Değerler (2018)}

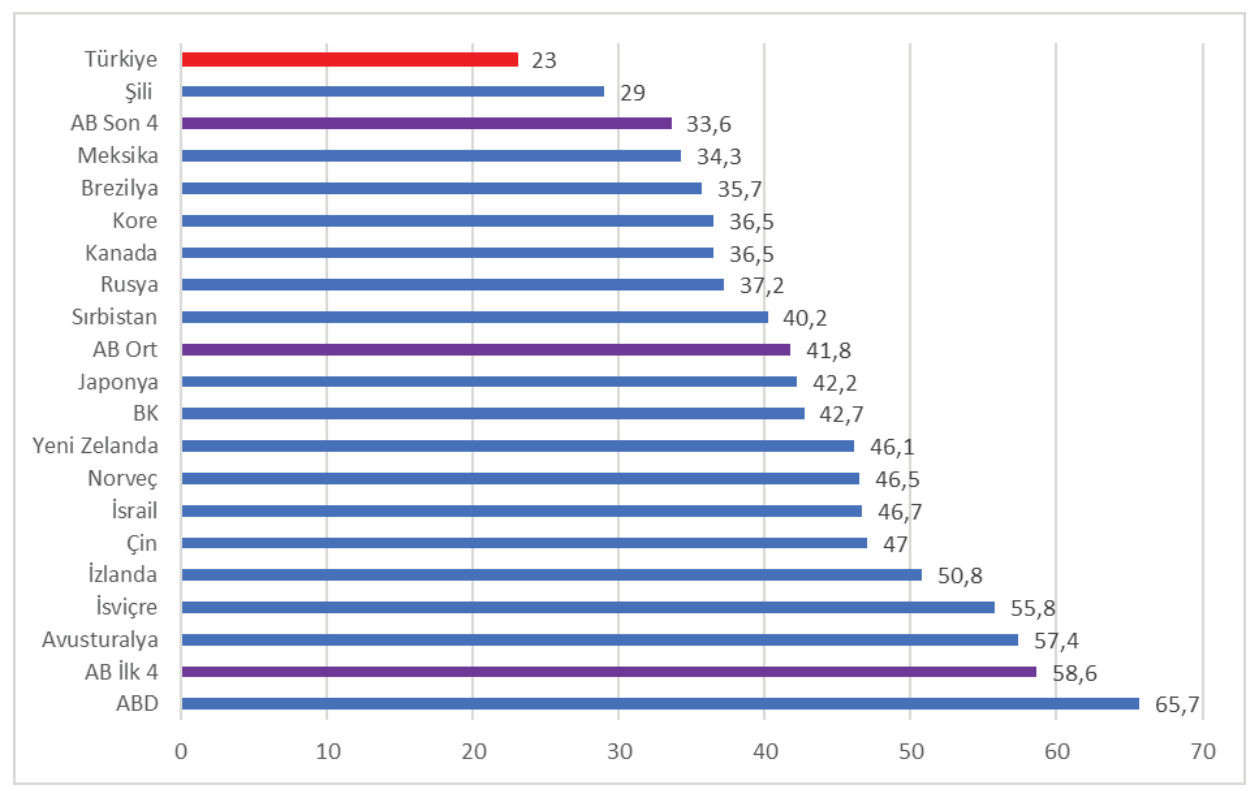

Kaynak: (European Commission, 2021, s. 23) verilerinden yararlanılarak hazırlanmıştır.

Dijital bir toplumun sunduğu olanaklardan yararlanmak için insanların sahip olmaları gereken becerilerin bir ifadesi olarak ortaya konulan Beşerî Sermaye Boyutu; temel beceriler, ileri düzeyde beceriler, temel yazılım becerileri, tam zamanlı Telekom çalışanlarını istihdamı ve Bilgi ve İletişim Teknolojileri (BIT) alanında mezun olanların göstergelerinden teşekkül olmaktadır. Grafik 4 incelendiğinde; Amerika Birleşik Devletleri'nin beşerî sermaye boyutunun 65.7 ile en yüksek seviyede olduğu görülmektedir. Illk 5'te yer alan diğer ülkeler ise sırasıyla AB İlk 4 ülkeleri ortalaması, Avusturalya, İsviçre ve İzlanda yer almaktadır. 
Dijitalleşme sürecinde Beşerî Sermaye Boyutu en düşük olan 5 ülke ise sırasıyla; Türkiye, Şili, AB son 4 ülkeleri ortalaması, Meksika ve Brezilya yer almaktadır. Türkiye'nin Beşerî Sermaye Boyutunun, diğer ülkelere kıyasla geride olmasının nedenleri arasında; eğitimin dijitalleşme sürecine tam uyumlu olmaması, işletmelerin büyük çoğunluğunun (\%99.8) KOBi'lerden oluşması ve bu tip işletmelerin Endüstri 4.0'a adapte olamamalarına paralel dijitalleşme sürecinde de geride kalmaları ve bu bağlamda dijitalleşme kapsamında yetenek, beceri ve yetkinlik düzeyine sahip üstün nitelikli başka bir ifade ile altın yakalı çalışanlara ihtiyaç duymamaları yer almaktadır.

Grafik 5. 2015 yılında Bilgi ve İletişim Sektöründe İşgücü Beceri İhtiyacı

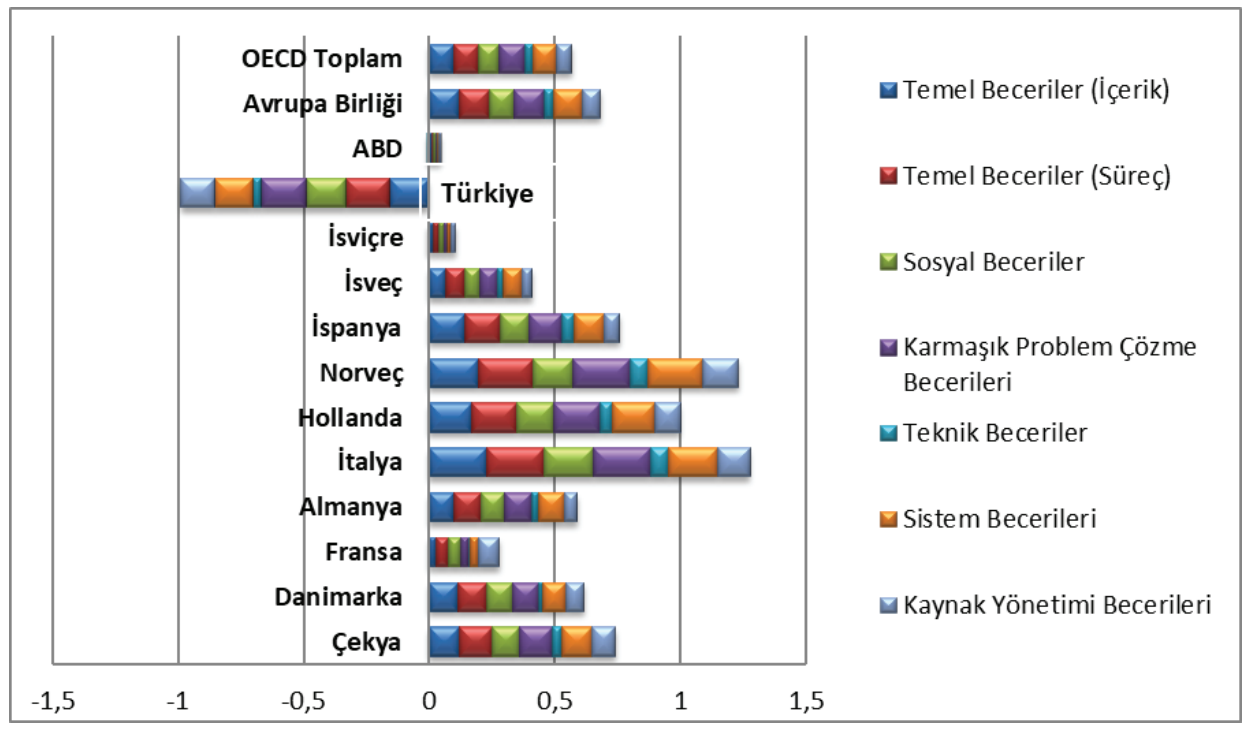

Kaynak: (OECD.Stat, 2020, 10, Eylül), verilerinden yararlanılarak hazırlanmıştır ${ }^{5}$.

Grafik 5 'te altı beceri türü kapsamında bir değerlendirme yapıldığında; pozitif değerler, işgücü piyasasında beşerî sermaye noktasında ihtiyaç duyulan beceri eksikliğini gösterirken, negatif değerler ise emek piyasasında beklenenden fazla düzeyde işgücü beceri fazlalığının olduğunu göstermektedir. Başka bir ifade ile pozitif değerler emek piyasasında beceri düzeylerine göre işgücü talep fazlalığını ifade ederken, negatif değerler emek piyasasında işgücü arz fazlalığını ifade

\footnotetext{
${ }^{5}$ Verilerin görülebilirliğini sağlamak adına tüm ülke verileri yerine seçilen bazı ülke verileri paylaşılmıştır.
} 
etmektedir. Bu bağlamda ortaya çıkan - 1 ile +1 arasındaki sonuçların mutlak değeri ne kadar 1'e yakın ise emek piyasasında yaşanan dengesizlik o oranda fazla olacaktır. Ayrıca sonuçların mutlak değerinin 1'den büyük olması durumunda, emek piyasasındaki dengesizlik daha fazla olacaktır.

Grafik 5'te yer alan veriler incelendiğinde; OECD Ülkeleri Toplamı ve Avrupa Birliği ülkelerinde, BIT (Bilgi ve Illetişim Teknolojileri) becerileri kazanmış işgücü açığı bulunmaktadır. Türkiye'de ise bu alanda BiT becerileri kazanmış işgücü fazlası olduğu görülmektedir. Bunun en önemli sebebinin, Türkiye'de büyük işletme ${ }^{6}$ sayılarının oranının \%0.2 olması neticesinde ileri teknolojiye sahip sermaye yoğun sektörlerin az olduğu savunulabilir. Grafik 4 ve Grafik 5 karşılaştıııldığında birbirini doğrulayan sonuçlar yer almaktadır. Bu bağlamda Grafik 4'de, ABD'nin beşerî sermaye boyutunun en üst seviyede olması, Grafik 5'te ise ABD emek piyasasının OECD ülkeleri arasında en dengede görünüm sergilemesi bunun açık bir kanıtıdır. Benzer değerlendirmeyi Türkiye için yaptığımızda da Grafik 4'te beşerî sermaye boyutunun en alt seviyede yer alması ve Grafik 5 'te hem emek piyasasında arz fazlasının olması hem de katsayının mutlak değerinin 1 olması emek piyasasında yaşanan dengesizliği göstermektedir.

Tablo 3: Büyüklük grubuna göre bilişim (ICT/IT) uzmanı istihdam eden girişimler, 2014-2020

\begin{tabular}{|l|c|c|c|c|}
\hline \multirow{2}{*}{ Referans dönemi } & \multicolumn{4}{|c|}{ Çalışan sayısına göre büyüklük grubu (\%) } \\
\cline { 2 - 5 } & Toplam & $\mathbf{1 0 - 4 9}$ & $\mathbf{5 0 - 2 4 9}$ & $\mathbf{2 5 0 +}$ \\
\hline 2014 & $\mathbf{1 0 . 5}$ & 7.1 & 20.5 & 53.7 \\
\hline 2015 & $\mathbf{1 3 . 8}$ & 9.4 & 26.9 & 57.6 \\
\hline 2016 & $\mathbf{1 3 . 0}$ & 9.2 & 23.5 & 55.3 \\
\hline 2017 & $\mathbf{1 0 . 8}$ & 6.8 & 22.5 & 53.4 \\
\hline 2018 & $\mathbf{1 1 . 6}$ & 8.2 & 24.3 & 57.4 \\
\hline 2019 & $\mathbf{1 3 . 7}$ & 10.1 & 26.3 & 64.8 \\
\hline 2020 & $\mathbf{1 1 . 8}$ & 7.7 & 25.9 & 66.3 \\
\hline
\end{tabular}

Kaynak: (TÜiK 2021, 29, Nisan) verilerinden yararlanılarak hazırlanmıştır.

Tablo 3'te TÜiK verileri incelendiğinde, Türkiye'de bilişim uzmanı (ICT/IT uzmanı) istihdamını 2014-2020 yılları arasında toplamda en yüksek orana sahip

\footnotetext{
${ }^{6} 250$ kişiden fazla çalışanı olan işletmeler.
} 
olduğu yıl \%13.8 ile 2015 iken en düşük oran ise \%10.5 ile 2014 yılında gerçekleşmiştir. 2020 yılında ise bu oran \%11.8'dir. İşletmelerin büyüklükleri incelendiğinde, dijitalleşmenin bir göstergesi olarak kabul edilen bilişim uzmanı istihdamının, en çok büyük işletmelerde, en az ise küçük işletmelerde gerçekleştiği görülmektedir. Küçük ve orta büyüklükteki işletmelerde 2014-2020 yılları arasında bilişim uzmanı istihdamı dalgalı bir seyir izlerken bu durum büyük işletmelerde genellikle artan bir seyir izlemektedir. Özellikle Covid - 19 pandemisinin en yoğun yaşandığı 2020 yılında KOBi'lerde bilişim uzmanı istihdamı azalırken, büyük işletmelerde artmaktadır. Toplamda bilişim uzmanı istihdamında yaşanan oransal azalmalar, KOBI'lerde yaşanan azalmalara bağlıdır. Bu Türkiye ekonomisinde olduğu gibi birçok ülkenin de yapısal ekonomik bir sorunu olarak karşımıza çıkmaktadır.

Tablo 4: Bilişim uzmanı alan veya almayı deneyen ve alım sürecinde güçlükle karşılaşan girişimler, 2013-2019

\begin{tabular}{|l|c|c|c|}
\hline $\begin{array}{l}\text { Çalışan sayısına } \\
\text { göre büyüklük } \\
\text { grubu }\end{array}$ & $\begin{array}{c}\text { Referans } \\
\text { Dönemi }\end{array}$ & $\begin{array}{c}\text { Bilişim uzmanı alan veya } \\
\text { almayı deneyen } \\
\text { girişimler (\%) }\end{array}$ & $\begin{array}{c}\text { Bilişim uzmanı alan veya almayı } \\
\text { deneyen girişimlerden güçlükle } \\
\text { karşılaşanlar (\%) }\end{array}$ \\
\hline \multirow{2}{*}{ Toplam } & 2018 & 5.7 & 47.3 \\
\cline { 2 - 4 } & 2019 & 5.0 & 41.0 \\
\hline \multirow{2}{*}{$\mathbf{0 - 4 9}$} & 2018 & 4.2 & 49.5 \\
\cline { 2 - 4 } & 2019 & 3.5 & 45.0 \\
\hline \multirow{2}{*}{$5 \mathbf{0 - 2 4 9}$} & 2018 & 9.8 & 41.9 \\
\cline { 2 - 4 } & 2019 & 9.5 & 34.0 \\
\hline \multirow{2}{*}{$\mathbf{2 5 0 +}$} & 2018 & 30.3 & 46.2 \\
\cline { 2 - 4 } & 2019 & 27.7 & 38.0 \\
\hline
\end{tabular}

Kaynak: (TÜiK 2021, 30, Nisan) verilerinden yararlanılarak hazırlanmıştır.

Tablo 4'te yer alan veriler incelendiğinde; KOBi'lerde ve büyük firmalarda, hem bilişim uzmanı alan ya da almayı deneyen firmalar hem de bilişim uzmanı alan veya almayı deneyen girişimlerden güçlükle karşılaşanlar, oransal olarak 2018 yılına nazaran 2019 yılında azalmaktadır. 


\section{Grafik 6. İnternet Hizmetinin Kullanım Boyutu İçin Normalleştirilmiş Değerler (2018)}

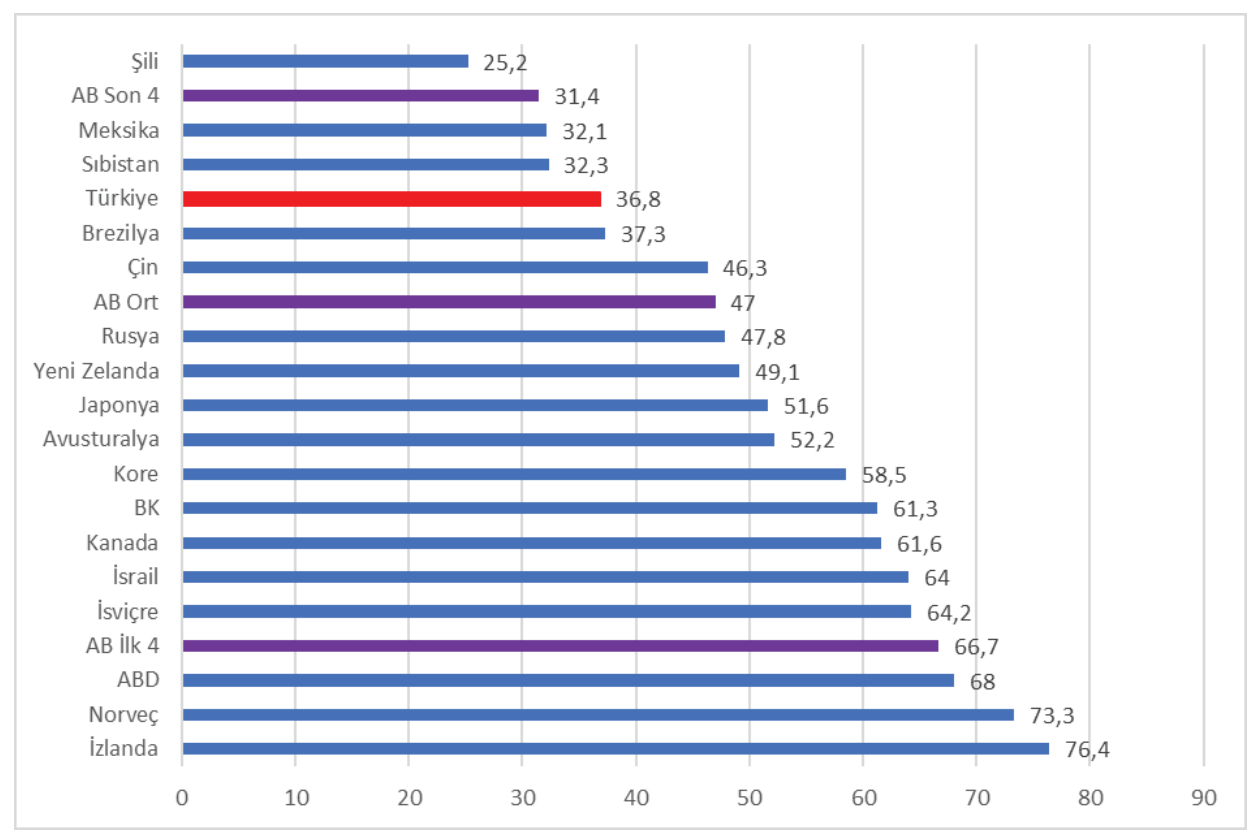

Kaynak: (European Commission, 2021, s. 26) verilerinden yararlanılarak hazırlanmıştır.

Internet Hizmetinin Kullanım Boyutu, bağlantı boyutu ile etkileşimi bulunan ve bağlantı boyutu ile sağlanan imkanların nasıl kullanıldığını gösteren bir boyuttur. Bağlantı boyutundan farklı olarak dijital yatırım düzeyini ölçmek yerine, özellikle bireylerin temel dijital becerilerinin gelişmesinde önemli rol oynayacak hem sosyal hem de ticari verileri de içeren ekonomik hayata dair değerleri yansıtmaktadır (European Commission, 2021, s. 25-27, 47, 48).

Bu bağlamda Internet Hizmetinin Kullanım Boyutu; internet kullanıcıları, sabit geniş bant trafiği, video görüşmeleri, sosyal ağlar, internet bankacılığı, çevrimiçi alışveriş göstergelerinden oluşmakta dolayısıyla çevrimiçi olan vatandaşlar tarafından gerçekleştirilen çeşitli faaliyetleri kapsamaktadır. Grafik 6 verileri dikkate alındığında internet hizmetinin kullanım boyutunun en iyi düzeyde olduğu ülkelerin başında \%76.4 ile İzlanda gelmektedir. İlk 5'te yer alan ve İzlanda'yı takip 
eden ülkeler sırasıyla; Norveç, $A B D, A B$ ülkeleri arasında en yüksek ortalamaya sahip ilk 4 ülke ve İsviçre yer almaktadır. Bu boyut değerinin en düşük olduğu beş ülke ise sırasıyla; \%25.2 ile Şili, AB ülkeleri arasında en düşük ortalamaya sahip son 4 ülke, Meksika, Sırbistan ve \%36.8 ile Türkiye yer almaktadır. I-DESI verileri kapsamında Türkiye'nin Bağlantı Boyutunda son sırada yer almasına rağmen Internet Hizmetinin Kullanılması Boyutunda dört basamak yukarı çıkması, internet kullanımının ülke genelinde tüm nüfusta yaygın olması nedenine bağlanabilir. Zira TÜiK'in 2020 yılının Haziran ayında yaptığı, "Hanehalkı Bilişim Teknolojileri (BT) Kullanım Araştırmasıı" na göre; internet kullanan bireylerin oranı 2014 yılında \%60 iken 2019 yılında \%88.3, 2020 yılında ise \%90.7'ye yükselmiştir. Yine internetten ürün siparişi verme ve ürün satın alma oranı 2014 yılınsa \%16.6 iken 2019 yılında \%34.1, 2020 ylında ise \%36.5'tir (TÜiK, 2021, 09, Mayıs).

\section{Grafik 7. Dijital Teknolojinin Entegrasyonu Boyutu}

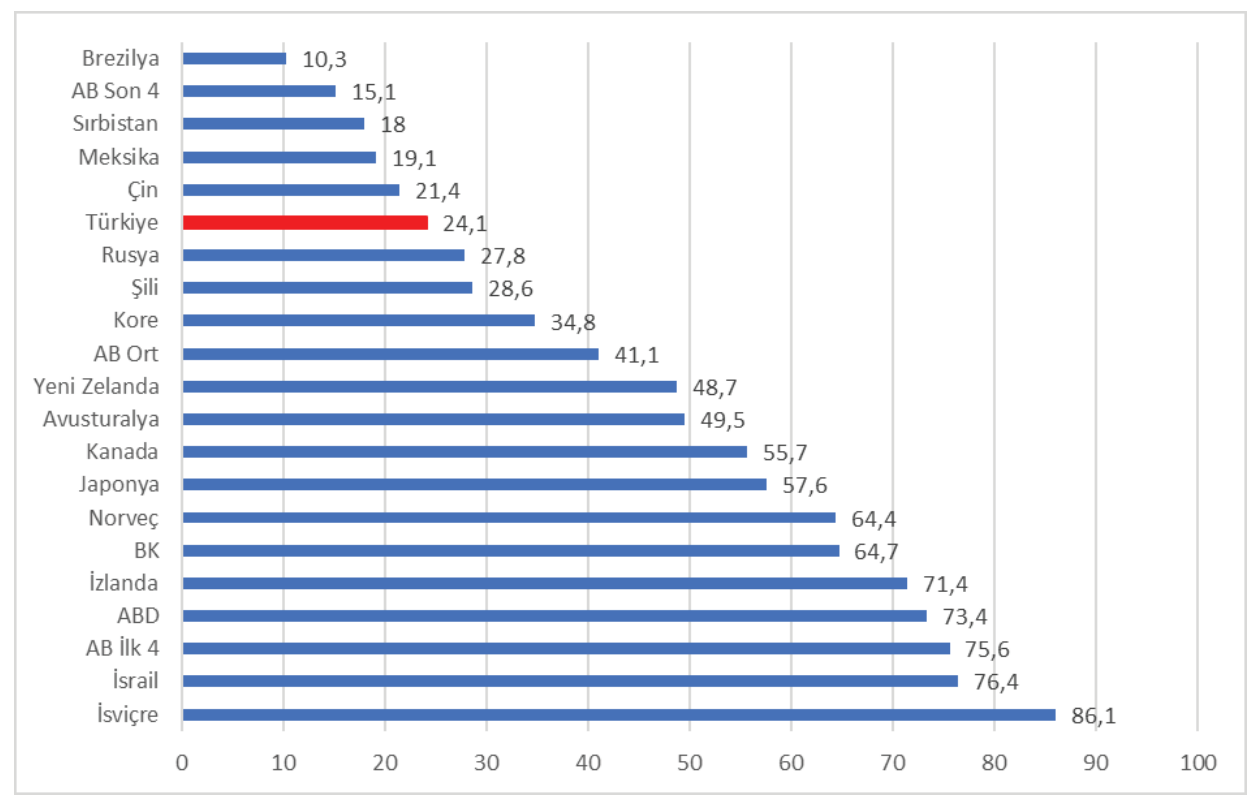

Kaynak: (European Commission, 2021, s. 29) verilerinden yararlanılarak hazırlanmıştır.

Dijital Teknolojinin Entegrasyonu Boyutu, işletmelerin dijitalleşmesi ve çevrimiçi satış kanallarının geliştirilmesini ölçmektedir. Başka bir ifade ile bu boyut, dijitalleşme sürecinin, üretim alanında hangi aşamada olduğunun en somut göstergeleri arasında yer almaktadır. Bu bağlamda işletme boyutunda dijital 
üretim metotlarını destekleyecek yatırımların ve KOBI'lerin sermaye gücü dikkate alındığında dijitalleşme sürecinde ileri teknolojiye ihtiyaç duyan sermaye yatırımlarının ne kadar yapıldığı, yapılan bu yatırımların dijital ekonomide kullanılabilirliği, dijitalleşmeye uyum sağlayan KOBi'lerin çevrimiçi satış (e-ticaret) kabiliyetleri ve e-ticaretin güvenli bir şekilde yapılabilmesinin sağlanması bu boyutun göstergeleri ile ölçülerek puanlandırılmaktadır (European Commission, 2021, s. 28-30, 48, 49).

En son teknolojilerin kullanılabilirliği, firma düzeyinde teknoloji yatırımı, çevrimiçi satış yapan KOBi'ler, güvenli internet sunucuları göstergelerinin bileşimi ile ölçülen Dijital Teknolojinin Entegrasyonu Boyutu ile ilgili Grafik 7'de verilen bilgiler dikkate alındığında, dijitalleşme sürecinin teknoloji entegrasyon boyutu değeri en yüksek olan ülke \%86.1 oranı ile İsviçre'dir. İsrail, AB ilk 4 ülke, ABD ve İzlanda bu boyutun en yüksek olduğu diğer dört ülkedir. Dijital Teknolojinin Entegrasyonu Boyutu en düşük olan beş ülke ise sırasıyla; Brezilya, AB son 4 ülke, Sırbistan, Meksika ve Çin'dir. Türkiye ise \%24.1 değeri ile son beşülkenin üzerinde yer almaktadır.

\section{Grafik 8. Dijital Kamu Hizmetleri Boyutu İçin Normalleştirilmiş Değerler}

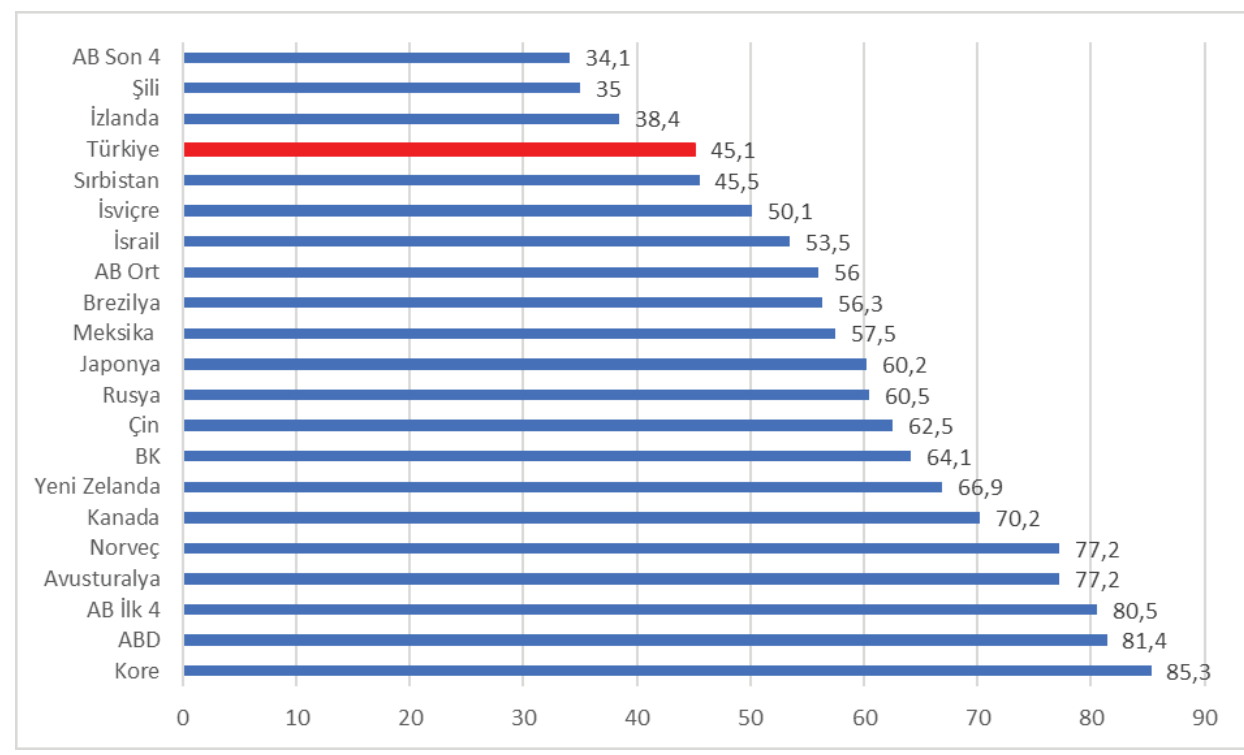

Kaynak: (European Commission, 2021, s. 32) verilerinden yararlanılarak hazırlanmıştır.

E-Devlet odaklı kamu hizmetlerinin dijitalleşme düzeyini ölçen Dijital Kamu 
Hizmetleri Boyutu; 16-74 yaş grubunda yer alan bireylerin dijital ortamda yer alan kamu hizmetlerini ve kamuya ait açık veri bankalarını hangi sıklıkta kullandıklarını, E- Devlet hizmetlerinin vatandaşa dijital platformda bilgi verme, danışma imkânı sunma ve vatandaşı karar alma sürecine dahil etme seviyelerini göstermektedir (European Commission, 2021, s. 31, 32, 49, 50). E-Devlet hizmetlerini sağlamasına bağlı olarak devlet, dijital ekonomiye geçişin önemli hızlandırıcıları arasında yer almaktadır.

Dijital Kamu Hizmetleri Boyutu; e- katılım endeksi, çevrimiçi hizmet tamamlama, açık veri göstergelerinden oluşmaktadır. Grafik 8'deki veriler dikkate alındığında Kore, ABD, AB Illk 4 ülke, Avusturalya, Norveç ve Kanada I-DESI'nin dijital kamu hizmetleri boyutunun en iyi düzeyde olduğu beş ülkedir. AB son 4 ülke, Şili, İzlanda, Türkiye ve Sırbistan ise sırasıyla bu boyut değerinin en düşük olduğu ülkeler arasında yer almaktadır.

\section{Dijitalleşmenin İşgücü Piyasasına Etkisi ve Verimlilik iliş̧kisi}

Dijitalleşme süreci işgücü piyasasını, çalışan yapısını, işlerin yapılış metotlarını, işin kendisini hatta üretim faktörlerinin dağılımını değiştirerek etkilemektedir. Literatürde teknolojiyi, üretim faktörlerinin beşincisi olarak kabul eden çalışmaların yanı sıra yardımcı üretim faktörü olarak kabul eden çalışmaların da olması, üretim faktörlerine karşı yeni bir bakış açısının geliştirilmesine neden olmuştur. Günümüzde özellikle yapay zekaya sahip robotların, başka bir isimlendirme ile "Cobot" ların, insan gücünün icra ettiği vasıflı ya da vasıfsız olarak tanımlanabilen işlerde işgücünün yerine ikame edilebilirlikleri, üretim faktörlerinin arasına bu çelik yaka iş̧̧ilerin dahil edilmesini zorunlu kılmıştır. Bu bağlamda çalışmanın bu bölümünde çalışanların dijitalleşme sürecinde değişen yapısını, teknolojik gelişmeler neticesinde yeniden şekillenmekte olan işgücü piyasasını ve bunların verimlilik üzerindeki etkileri açıklanmaya çalışılacaktır.

Teknolojik gelişmelerin çalışma hayatına etkileri incelendiğinde, öncelikle her makineleşme düzeyinin, işin yapılışs şeklini değiştirdiği, bu etki ile beraber birçok yeni işin ortaya çıktığı aynı zamanda mevcut işlerin bir kısmının ise ya değiştiği ya 
da ortadan kalktığı bilinmektedir. Bu iki sonuç arasında denge sağlanamaması ve dengenin mevcut işlerin ortadan kalkmasından yana ağır basması işgücü piyasasında istihdam sorunlarının önemli bir nedeni olarak karşımıza çıkmaktadır (Coşan, 2020, s. 235).

Makineleşme sanayi devrimi ile birlikte tüm dünyaya yayılmış, endüstri sektörü başta olmak üzere tarım ve hizmetler sektörlerinde de makineler üretimde önemli görevler üstlenmişlerdir. Teknolojinin üretimde toplam faktör verimliliğinin yanı sıra işgücü verimliliğini de arttırdığı bilinmektedir. Makineleşme ve otomasyon dalgaları bazı sektörlerde ve mesleklerde işleri ya ortadan kaldırmış ya da değiştirmiştir. Bununla birlikte işgücü becerilerinin, yetkinliklerinin ve yeterliliklerinin sürece uygun şekilde yeniden dönüştürülmesi, makine - insan senkronizasyonunu arttırmış ortaya çıkacak işsizliğinin önemli derecede önüne geçilmiştir. Bunun en bariz örneği 19. ve 20. yüzyıllarda yaşanmış, işgücünün, makineleşme ve otomasyon sürecine sektörel geçişleriyle çözüm bulunmuştur (Brynjolfsson \& McAfee, 2012, s. 37). Bu yüzyıllarda ortaya çıkan uyumun temelinde, teknolojik dönüşüm hızının yavaş olması yatmaktadır. Günümüzde teknolojik değişim ve dönüşüm hızının çok yüksek olması, emeğin iş piyasalarında yenilenen üretim metotlarına ve işlere uyum hızını düşürmektedir.

Makineleşme sürecini de iki kısımda incelemek mümkündür. Sanayi devriminden itibaren 20.yy'ın sonlarına kadar devam eden "Birinci Makineleşme Çağı"nda makinelerin, çalışanların işini daha rahat yapabilmesini sağlayan araçlar iken 21.yy'da yazılım sektörünün gelişimine bağlı olarak ortaya çıkan "ikinci Makineleşme Çağı"nda; yapay zekâ ve tam otomasyon gibi süper teknolojiler, üretim sürecinde insanın yerine makinenin ikame edilmesine neden olsa da üretimi ve verimliliği arttırmaktadır. Bununla birlikte olumsuz yönden bir tahlil ile bu teknolojilerin sadece mavi yakalı çalışanların değil aynı zamanda beyaz yakalı çalışanların da teknolojik işsizliğine neden olacağı ifade edilmektedir (Arthur, 2021).

1930 yılında Keynes "Economic Opportunities for Our Grandchildren" (Torunlarımız İçin Ekonomik Olanaklar) adlı makalesinde; teknolojide yaşanacak gelişmelerin etkisiyle 100 yıl sonra (2030 yılı için) üretimin, yeterli düzeye çıkacağı 
hatta bu üretimin, işgücünün çalışma saatlerinin haftalık 15 saate kadar düşürülerek gerçekleştirilebileceğini, buna karşın üretimdeki verimliliğe dayalı bu artışın teknolojik işsizliği meydana getireceğini ifade etmiştir. Bu öngörünün günümüz ile kısmen tutarlı olduğu görülmektedir. Bu bağlamda makineleşme, otomasyon, dijitalleşme süreçleri dikkate alındığında ABD'nde, 1930 yılında işgücünün mevcut çalışma saatleriyle gerçekleştirilen üretim miktarına, henüz 100 yıl geçmeden 1977 yılında işgücünün ortalama haftalık 15 saat çalışması ile ulaşılmış olması, Keynes'in verimliliğin artışına mukabil üretimin yeterli düzeye çıktığı öngörüsünü doğrulamaktadır. Bununla beraber günümüzde OECD ülkelerinde ortalama çalışma süreleri haftalık ortalama 34 saattir. Bu noktadan hareketle teknolojinin verimliliği (işgücü verimliliği de dahil) arttırdığı, bunun bir neticesi olarak üretim ve ürün miktarının da arttığı ama yine de emeğin çalışma saatlerinin Keynes'in öngördüğü şekilde azalmadığı, başka bir ifade ile üretim verimliliğinden kaynaklanan refahın, emeğe çalışma süreleri bağlamında doğrudan yansıtılmadığı görülmektedir. Ayrıca burada Keynes'in kavrayamadığı başka bir nokta, insan istek ve arzularının derinliğine bağlı olarak tüketici talebinin değişen derinliğiydi. İşgücünün üretim miktarına bakılarak 15 saat yerine 34 saat çalışmasının nedeni, teknolojinin daha ucuz ve daha iyi hale getirdiği ürün ve hizmet talebinin artmasıdır. Otomasyon ve dijitalleşme kaynaklı kitlesel işsizliğin diğer birçok başarısız tahmininin arkasında da benzer bir eksik talep tahmininin yatmakta olduğu düşünülmektedir (Bessen, 2019).

Dijitalleşen dünyada makineleri, akıllı ya da yapay zekaya sahip olarak nitelendirebilmek için öncelikle o makinelerin bir insan tarafından programlanması gerekmektedir. Dolayısıyla bir yazılım sürecinin içinde yer almayan makinelerin yine doğal insan irade ve zekasına bağımlı olduğu bilinmektedir. Yazılımın sanal bir ürün ve tek maliyetinin ise üretim faktörlerinden hammadde ve malzeme gibi maddi değil beşerî sermayenin zihinsel yatırımı olması, yazılımı diğer ürünlerden farklı kılmaktadır. Ayrıca yazılımın tek defa yapılmasının ardından kopyalanarak kullanılabilmesi, beşerî sermaye maliyetini de azaltmakta hatta neredeyse bu maliyeti sıfırlamaktadır. Yazılım gibi maddi olmayan dijital ürünlerin verimlilik üzerindeki etkilerini araştıranların ortak noktası dijital varlıkların, işgücü verimliliğini ve toplam faktör verimliliğini olumlu etkilediği yöndedir (Bertani, Raberto \& Teglio, 2020). 
Dijitalleşme sürecinde dikkat çeken ve gelecek üretim metotlarını kökten değiştirebilecek önemli başka bir husus ise yapay zekanın üretim faktörleri arasına dahil edilmesidir (Acemoglu \& Restrepo, 2018, s. 48). Yapay zekanın işlevselliği açısından, üretim faktörlerinden emek ile aynı kota da düşünülmesi ise geleceğin planlanan istihdam yapısı üzerinde de bize ayrıca bir öngörü sunmaktadır. Bu bağlamda sanayi devrimi ile birlikte belirginleşen insan emeğinin nasıl muhafaza edileceği sorusu dijitalleşme süreci ile birlikte, çözümlenmesi gereken daha önemli bir problem olarak bizi beklemektedir.

\section{Literatürde Dijitalleşme ve Verimlilik iliş̧kisi}

Teknolojik gelişmelerin sermaye yoğun üretimi desteklemesi, yeni nesil otomasyon modelinin, bir üretim faktörü olarak hem daha ucuz hem de daha üretken olmasılla emeği ikame edeceğini ve verimliliğin artacağını savunan yazarların yanı sıra otomasyonun işgücü verimliliğini arttırarak emeğin kıymetini de arttırdığını savunanlar yazarlar da vardır.

Brynjolfsson ve McAfee 'nin (2012) çalışmalarında, beyaz yakalı işlerin yanı sıra mavi yakalı işlerin de akıllı makineler tarafından icra edileceği, bu bağlamda çalışanların istihdamının, ücretlerinin ve refahının dijitalleşme sürecinden olumsuz etkileneceği vurgulanırken, vasıflı ve vasıfsız çalışan ayrımı yapılmaksızın işgücü piyasasının akıllı makineler başka bir ifade ile endüstriyel robotlar ${ }^{7}$ (akıllı robot teknolojileri) ile ikame edileceği öngörüsünde bulunulmaktadır. Ayrıca verimliliğin akıllı robot teknolojisiyle yenilenmiş otomasyon ile artacağı öngörüsü de çalışmada yer almaktadır.

Sachs ve Kotlikoff (2012), dijitalleşmenin neticesinde ortaya çıkan teknolojilerin vasıflı işgücünün verimliliğini arttırırken vasıfsız işgücünün marjinal verimliliğini azaltacağı tahmininden hareket ettikleri çalışmalarında, diğer çalışmalardan farklı olarak, dijitalleşme sürecinin nesiller arasında ortaya çıkaracağı eşitsizliğe değinilmiştir. Bu kapsamda yaşlı emeğin maddi ve beşerî sermaye biriktirmiş

\footnotetext{
${ }^{7}$ Bu kavram "Cobots (Collaborative Robots, İşbirlikçi Robotlar)" olarak adlandırılmaktadır.
} 
olmalarının, genç işgücünün ise henüz işgücü piyasasına girecek olmasından kaynaklanan hem maddi hem de beşerî sermaye eksikliği karşısında yaşlı işgücünün avantajı duruma geçeceğini savunmaktadırlar. Burada çalışmada yer almayan ama başka önemli bir sorun ise yaşlı nüfusun emeklilik nedeniyle işgücü piyasasından emeğini çekecek olması, ortaya çıkacak nitelik eksikliğinin ise kısa zamanda tamamlanamayacağı gerçeğidir.

Nordhaus (2015), vasıflı emeğin sermaye ile ikame edilebilirliğinin yüksek ancak mükemmel olmadığını, vasıfsı işgücünün bilgi teknolojisi ile ikame edilmeye yatkın olmayan tek grup olduğunu savunmaktadır. Bununla beraber çalışmada üretim verimliliğinin ise artacağı ifade edilmektedir.

Piva ve Vivarelli'nin (2017) çalışmalarında, teknolojik ilerlemelerin; dijitalleşme sürecinde ihtiyaç duyulan işgücünden beklenen nitelik, yetenek ve becerilerinin artmasına mukabil işgücünün altın yakalı olarak ifade edilen ileri vasıflı, çok yönlü yeteneğe sahip, yeniliklere hızlı adapte olabilen yeterlilikte insan gücü arasından tercih edilmesi, ücretlerde ve gelirde artışa neden olması, yeni sermaye yatırımı yapılması ve buna paralel sermaye yoğun sektöre uyumlu ek istihdam alanlarının açılması, teknolojinin de etkisiyle verimlilikte yaşanacak artışların ürün piyasasını olumlu etkileyerek ürün piyasasında fiyatların düşmesi ve bu durumun ücretlerin satın alma gücünü arttırması, ürün piyasasına yeni ürünlerin arz edilmesi nedenlerine bağlı olarak işsizliği arttıııı etkisinin dengeleneceği düşüncesi savunulmaktadır.

Graetz ve Michaels (2018), otomasyonun esnek, çok yönlü ve endüstriyel robotlar tarafından yapıldığının, robot kullanımının hem toplam faktör verimliliğini hem de işgücü verimliliğini arttırdığını, işgücü verimliliğini ise 0,36 arttırdığını tespit etmişlerdir. Robot otomasyonunun gelişmiş ülkelerin endüstri sektörlerinde kullanıldığı, son zamanlarda ise hizmetler sektöründe de bu dönüşümün görüldüğü ifade edilmektedir. Bu kapsamda; tıbbi robotların, fabrika lojistik sistemlerinin ve insansız hava araçlarının en sık kullanılan robot teknolojisi olduğu tespitine yer verilmektedir. Ayrıca robotların, işgücü piyasasını kısmen etkilediği, bu bağlamda vasıfsız işgücünün robotlaşmadan negatif etkilenmekte olduğu belirtilmiştir. Bazı vasıflı sayılabilecek mesleklerin de önümüzdeki yıllarda dijitalleşme sürecinden 
negatif etkilenebileceği, çalışmada emek piyasası hakkında varılan öngörüler arasında yer almaktadır.

Autor ve Salomons (2018), yaptıkları çalışmada, teknolojik yeniliklerin işgücünü makine ile ikame edeceğini ama bu durumun toplam emek talebinde bir azalmayı zorunlu kılmayacağını savunmaktadırlar. Çalışmada, dijitalleşme neticesinde ortaya çıkan dijital ve teknolojik dönüşümden işgücü piyasasında emek talebinin negatif yönlü etkilenmesini önleyen faktörler olduğu ifade edilmiştir. Bunlar, dijitalleşme sürecinde işgücü istihdamının dengede kalmasını sağlayan, doğrudan ve dolaylı faktörler olarak sınıflandırılmışır. Doğrudan etki verimlilik artışlarından kaynaklanmakta iken dolaylı etki ise endüstride üretim faktörleri portföyünün makine - insan bileşiminden ve endüstriler arası üretim faktörü talep bağlantılarından kaynaklanmaktadır. Ayrıca çalışmada dijitalleşmenin ve otomasyonun toplam faktör verimliliğini arttıırken, emeğin katma değerini düşürdüğü tespit edilmiştir.

Bessen (2019) yaptığı araştırmasında, makineleşmenin neticesinde ortaya çıkan otomasyonun, işgücü verimliliğini ve genel verimliliği arttırdığını, bununla beraber otomasyon üretkenliğinin makinelerin insan gücüne alternatif oluştursa da işsizliğine neden olmadığını dahası istihdamdaki değişikliklerin otomasyonun ortaya çıkardığı gerek insan gücü gerekse makine gücü verimliliğinin artışından ziyade talep esnekliğinden kaynaklandığını savunmaktadır. Buna ek olarak yeni teknolojilerin gelirin yeniden dağıtılmasına neden olacağı, bunun ise basit makineleşme dönemlerinde makinelerin sadece niteliksiz ya da yarı nitelikli işleri yerine getiren mavi yakalıların yaptığı işleri icra etmesinden, günümüzde ise yapay zekaya sahip ileri teknoloji ürünü makinelerin varlığıyla birlikte makinelerin (endüstriyel robotların), mavi yakalıların yanı sıra nitelikli ve profesyonel işleri yerine getiren beyaz yakalıların da yaptığı işleri icra edebilmesinden kaynaklandığını savunmaktadır. Bununla birlikte çalışmada, insan istek ve ihtiyaçları 10-20 yıl içerisinde anlamlı düzeyde değişmeyeceği başka bir ifade ile talepte yaşanacak değişimlerin dramatik düzeyde gerçekleşmeyeceği, bu durumun ise teknolojinin meydana getireceği işsizliği azaltacağı ifade edilmektedir.

Metlyakhin, Nikitina, Yarygina ve Orlova (2020) Rusya Federasyonu bölgelerindeki işgücü verimliliği düzeyini etkileyen temel dijitalleşme faktörlerinin 
araştııılması üzerine yaptıkları ekonometrik çalısmada, panel veri analizi ile ölçüm yapılmıştır. Çalışmada; dijitalleşmenin ve dijital ekonominin, işgücü verimliliğini etkilediği sonucuna varılmıştır. Bu bağlamda internet erişiminin kontrollü olması kaydıyla, çalışma ortamlarının; bilgisayarlı, geniş ağ bağlantısına ve yüksek düzeyde otomasyona sahip işlerde işgücü verimliliğinin önemli düzeyde pozitif etkilendiği tespit edilmiştir. Bununla beraber kontrolsüz sağlanan internet erişiminin, işgücünün çalışma saatlerini kullanmasında meydana getirdiği negatif etki ile işgücü verimliliğini negatif etkilediği vurgulanmaktadır. Son olarak şirketlerin Web sitelerinin olup olmamasının ise işgücü verimliliğini etkilemediği sonucuna varılmıştır.

Akaeva ve Sadovnichiib (2021) yaptıkları çalışmada, dijitalleşme sonucunda işgücü verimliliğinin nasıl etkileneceğinin yanı sıra işgücünün bu süreçte istihdamının nasıl etkileneceğini de araştırmışlardır. Dijitalleşme ve insan gücü istihdamı üzerine yaptıkları araştırmada, dijital çağdaki bilişsel çalışmaların çoğunun, akıllı makineler tarafından ikame edilemeyeceğinden, insan emeği için ayrılmaya devam edeceğini savunmaktadırlar. Ayrıca insan ve akıllı makine iş birliğinin, dijital teknolojiler kullanılması durumunda işgücü verimliliğinin artacağını, bu birliktelikte insan emeğinin ağır basması durumunda emek verimliliğinin en üst seviyeye çıkacağı, insan - akıllı makine birlikteliğinde akıllı makinelerin ağırlık göstermesi durumunda ise işgücü verimliliğinin en alt seviyeye ineceği tespit etmişlerdir. Bunlara ek olarak gelişmiş ülkelerde işgücü verimliliğinin 2020 ortalarına kadar \%3 seviyesinde olacağı ve bu seviyenin 2040'lara kadar korunabileceğini öngörmektedirler.

\section{Sonuç}

Dünya nüfusunun yanı sıra Türkiye'de de nüfusun yaşlanması genç nüfusun değerini arttırmaktadır. Genç işgücünün emek piyasasında verimliliğinin az olduğunu savunanların, genç çalışanların tecrübe eksikliğini ön plana çıkardıkları göz önüne alındığında, ulusal eğitim modelinin dijital ekonomiye uyumlu hale getirilmesi gerekmektedir. Dijitalleşme sürecinde yaşanan, genç işgücünün dijital dönüşüme uyumu, ulusal eğitim programlarının değiştirilerek, sadece teoride 
verilen eğitim metodunun ötesine geçilerek teori \%30 uygulama \%70 modelinin uygulanması bu soruna bir çözüm olabilecektir. Ayrıca dijitalleşmenin bir fırsata dönüştürülmesi adına yaşlı işgücünün de, beden ile yapılmayan işlerde daha aktif olmaları hem aktif nüfusun artmasına dolayısıyla üretimin de artmasına hem de sosyal güvenlik sisteminin yükünün hafifletilmesine neden olacaktır. Ayrıca yaşlı ve genç işgücünün dijitalleşme sürecinde bir araya getirilmesi, nesiller arasındaki iletişimin artmasını sağlayacak böylece kültürel süreklilik de devam edecektir.

Dijital ekonomide nitelikli işgücünden beklenen beceri, yetkinlik ve yeterliliklerin, ülke ihtiyaçlarının yanı sıra bölgesel ve küresel ihtiyaçların da gözetilerek işgücüne aktarılması, daha dinamik bir dijital toplumun kurulmasını sağlayacaktır. Bireylerde yeteneklerin hem doğuştan var olması hem de sonradan kazanılarak elde edilmesi, insan gücünün yeteneklerinin okul döneminde tespit edilmesini ve öğrencilerin IQ zekayı ölçen sınavlar yerine, yetenekleri belirleyen ölçümlerle eğitimlerini devam ettirilmelerini gerekli kılmaktadır. Bunlara ek olarak beyin göçü ile yurtdışına göçmüş insan gücünün geri dönmesini sağlayacak reel politikaların belirlenmesi ve uygulanması, sağlam yapıda oluşturulmuş bir dijital toplum esasında, üretim verimliliğinin yanı sıra kalitesini de arttıracaktır.

Dijitalleşme sürecinde maddi ve beşerî sermaye farklılıklarından kaynaklanan eşitsizliğin öncelikle ücretlerde ortaya çıkacağı düşüncesi, bu sorunun yeni bir vergilendirme sistemi ile birlikte çözümlenebileceği düşüncesini destekler niteliktedir. Ayrıca vergilendirmenin yanı sıra diğer transfer politikaları, sosyal politikalar ve aktif işgücü piyasası politikalarının da etkin bir şekilde kullanılması, yukarıda anılan eşitsizliğin giderilmesinde önemli bir rol oynayacaktır. Bu bağlamda neo liberal politikaların yeniden gözden geçirilmesi, ulusal bir ekonomik perspektifin kazanılması dahası eğitim programlarının da bu çerçevede sadece eğitim kurumlarında değil, tüm yaşama dağıtılarak hayat boyu eğitim seviyesine taşınması, toplumda hem ekonomik hem de sosyal açıdan denge ve bütünleşme fırsatı doğuracaktır.

Literatürde dijitalleşme sürecinin, işgücü verimliliğini genellikle pozitif etkileyeceği görüşü ağır basmaktadır. Bununla beraber akıllı makinelerin ve 
robotlaşan otomasyon sistemlerinin, sadece işgücü verimliliğini değil aynı zamanda toplam faktör verimliliğini de olumlu yönde etkileyeceği düşünülmektedir. Teknolojik gelişmelerle birlikte çağımızın yenilikleri arasında yer alan akıllı makineler, yapay zekaya sahip makineler ya da başka bir adıyla insanımsı makineler, üretim faktörlerinin arasına dahil edilmekte ve üretim faktörlerinden emeği ikame etmesi beklenmektedir. Tüm bunlara rağmen insan gücünün ürün piyasasının vazgeçilmez bir girdisi olduğu genel kabul gören başka bir husus olarak karşımıza çıkmaktadır. Tarım devrimi ile sanayi devrimi arasında olan zaman kavramının, sanayi devrimi ile dijital devrim ile benzerlik taşıması, emeğin bu süreçten zararlı çıkma endişesini de arttırmaktadır. Ayrıca dijitalleşme ile birlikte sanal organizasyonların sayısının artması, emek piyasasının ve işlerin icra edilmesinin de şekil değiştirmesi endüstri ilişkilerinin de yeniden düzenlenmesini zorunlu kılacaktır.

AB'nin I-DESI ölçümleri çerçevesinde inceleme yapıldığında Türkiye'nin dijitalleşme sürecinde oldukça yetersiz olduğu görülmektedir. Bu durumun Türkiye'nin sanayileşme süreçlerinin eksik bir şekilde gerçekleştirilmesinin önemli bir payı vardır. Ayrıca dijital dönüşümün ekonomiye yansıtılması için mevcut şirketlerin bu süreci kaldırabilecek kadar yeterli sermayelerinin olup olmadığı önem arz etmektedir. Bu çerçevede düşünüldüğünde, Türkiye'de büyük işletmelerin, tüm girişimler arasındaki payının \%0.2'lik, KOBi'lerin ise \%99.8'lik bir orana sahip olması dijital ekonomiye geçişte, Türk ekonomisinin zayıf yönü olarak ifade edilebilir.

Türkiye'deki işletmeler arasında KOBi'lerin yoğunluğu dikkate alındığında, dijitalleşme sürecinde emek yoğun üretim tarzının ileri teknolojiye sahip sermaye yoğun sektörlere kayması, bunun için gerekli maddi ve beşerî sermayenin maliyetinin KOBi'ler tarafından karşılanamaması devletin bu işletmeler için önlem almasını elzem kılmaktadır. Bu bağlamda;

- Dijitalleşme sürecinde etkin olarak kullanılan yeni araçların KOBi'lere destek programları çerçevesinde verilmesi

- KOBi'lerin fikri mülkiyetten daha iyi yararlanması, korunması ve diğer gayri maddi varlıklardan yararlanması adına önündeki engellerin kaldırılmasına 
yardımcı olan önlemler alınması.

- KOBi'lerin dijitalleşme sürecine uyumunu kolaylaştıracak, bazı kurallarda muafiyet haklarının tanınması

- KOBílerin ölçeklerini büyütmeleri için caydırıcı unsurları içeren politikaların ortadan kaldırılması

- Farklı politika alanlarında uygulanan tüm politika önlemleri, arasında uyum ve koordinasyonu sağlamak için ulusal bir dijital strateji politikası oluşturulmalıdır.

Hakem Değerlendirmesi: Dış bağımsız.

Çıkar Çatışması: Yazar çıkar çatışması bildirmemiştir.

Finansal Destek: Yazar bu çalışma için finansal destek almadığını beyan etmiştir.

Peer-review: Externally peer-reviewed.

Conflict of Interest: The author has no conflict of interest to declare.

Grant Support: The author declared that this study has received no financial support.

\section{Kaynaklar/References}

Acemoglu, D., \& Restrepo P. (2018). Modeling automation. AEA Papers Pro, 108, 48-53.

Akaeva, A. A., \& Sadovnichiib, V. A. (2021). The human component as a determining factor of labor productivity in the digital economy. Studies on Russian Economic Development, 32(1), 29-36.

Andrews, D., Nicoletti, G., \& Timiliotis, C. (2018). Going digital: what determines technology diffusion among firms?. OECD Economics Department Working Papers, 1466, Paris: OECD Publishing.

Andrews, D., Criscuolo C., \& Gal P. (2016). The Best versus the rest: the global productivity slowdown, divergence across firms and the role of public policy. OECD Productivity Working Papers, Paris: OECD Publishing.

Arthur, W. B. (2021, March). Where is technology taking the economy?. Erişim adresi: https://www.mckinsey. com/business-functions/mckinsey-analytics/our-insights/where-is-technology-taking-the-economy

Autor, D., \& Salomons, A. (2018). Is Automation labor share-displacing? Productivity growth, employment, and the labor. Brookings Papers on Economic Activity, 1-63.

Bertani, F., Raberto, M., \& Teglio, A. (2020). The productivity and unemployment effects of the digital transformation: an empirical and modelling assessment, Review of Evolutionary Political Economy, 1, 329-355.

Bessen, J. (2019). Automation and jobs: when technology boosts employment, Economic Policy, 34(100), 589-626.

Brynjolfsson, E., \& McAfee, A. (2012). Race against the machine: How the digital revolution is accelerating innovation, driving productivity, and irreversibly transforming employment and the economy. Digital Frontier Press. 
Brynjolfsson, E., Rock, D., \& Syverson, C. (2017). Artificial intelligence and the modern productivity paradox: A clash of expectations and statistics. NBER working paper, 24001, Cambridge: National Bureau of Economic Research.

Bükey, A.M. ve Akgül, O. (2019). Teknoloji transferinin gelir dağılımına olan etkisi: Türkiye örneği. Siyaset, Ekonomi ve Yönetim Araştırmaları Dergisi, 7(1), 1-8.

Calvino, F., Criscuolo, C., Marcolin, L., \& Squicciarini M. (2018). A taxonomy of digital intensive sectors. OECD Science, Technology and Industry Working Papers, 2018/14, Paris: OECD Publishing.

Coşan, B. (2020). Endüstri 4.0'dan Toplum 5.0'a teknoloji ve işsizlik. B. Yılmaz (Ed.), Çalışma hayatının geleceği kitabı içinde (s. 219-254). Ankara: Gazi Kitabevi.

Dünya Ekonomik Formu (World Economic Forum). (2018). The Future of Jobs Report 2018. Genava.

European Commission. (2021). International Digital economy and society index 2020. Smart 2019/0087 Final Report.

Gal, P., Nicoletti, G., Renault, T., Sorbe, S., \& Timiliotis, C. (2019). Digitalisation and productivity: In search of the holy grail - Firm-level empirical evidence from EU countries. OECD Economics Department Working Papers. 1533, Paris: OECD Publishing.

Gökalp, E. , Gökalp, M. O., Çoban, S. ve Eren, P. E. (2019). Dijital dönüşümün etkisinde verimli istihdam yönetimi: yol haritası önerisi. Verimlilik Dergisi, (3), 201-212.

Graetz, G., \& Michaels, G. (2018). Robots at work. The Review of Economics and Statistics, 5, 753-768

Haskel, J., \& S. Westlake (2018). Capitalism without capital: the rise of the intangible economy. New Jersey: Princeton University Press.

Metlyakhin, A.I., Nikitina, N.A., Yarygina, L.V., \& Orlova, E.O. (2020). Analysis of the impact of economy digitalization on labor productivity in Russia. St. Petersburg State Polytechnical University Journal. Economics, 13(2), 7-17.

Nordhaus, W.D. (2015). Are we approaching an economic singularity? Information technology and the future of economic growth. Working Paper 21547, National Bureau of Economic Research.

OECD.Stat (2020, Eylül). ICT Access and Usage by Businesses. Erişim adresi: https://stats.oecd.org/ Index.aspx?DataSetCode=ICT_BUS.

OECD (2021, Mart). Productivity Growth in the Digital Age. Erişim adresi: https://www.oecd.org/ going-digital/productivity-growth-in-the-digital-age.pdf

Piva, M., \& Vivarelli, M. (2017). Technological change and employment: Were Ricardo and Marx right?. IZA Discussion Papers, 10471.

Sachs, J.D., \& Kotlikoff, L.J. (2012). Smart machines and long term misery. Technical Report, 18629, National Bureau of Economic Research.

T.C. Kalkınma Bakanlığı. (2018). On birinci kalkınma planı (2019-2023) sanayide dijitalleşme çalışma grubu raporu. Ankara

TÜiK. (2021, 16, Mart). Küçük ve orta büyüklükteki girişim istatistikleri, 2019. Erişim adresi: https:// tuikweb.tuik.gov.tr/PreHaberBultenleri.do?id=37548 
TÜiK. (2021, 29, Nisan). Girişimlerde bilişim teknolojileri kullanım araştırması, 2014-2020. https://data. tuik.gov.tr/Kategori/GetKategori?p=Bilim,-Teknoloji-ve-Bilgi-Toplumu-102

TÜiK. (2021, 30, Nisan). Bilişim uzmanı alan veya almayı deneyen ve alım sürecinde güçlükle karşılaşan girişimler araştırması, 2013-2019. Erişim adresi: https://data.tuik.gov.tr/Kategori/ GetKategori?p=Bilim,-Teknoloji-ve-Bilgi-Toplumu-102

TÜiK. (2021, 09, Mayıs). Hanehalkı bilişim teknolojileri (BT) kullanım araştırması 2020. Erişim adresi: https://data.tuik.gov.tr/Bulten/Index?p=Hanehalki-Bilisim-Teknolojileri-(BT)-KullanimArastirmasi-2020-33679.

Yılmaz, B. (2020). Geleceğin meslekleri. B. Yılmaz (Ed.), Çalışma hayatının geleceği kitabı içinde (s. 79-123). Ankara: Gazi Kitabevi.

Yılmaz, Y. (2020a). İsgücü verimliliği: etkileyen faktörler. Ankara: Gazi Kitabevi.

Yılmaz, Y. (2020b). Dijitalleşmenin etkisi altında değişen çalışan yapısı geleceğin işgücü yetkinlikleri. B. Yılmaz (Ed.), Çalışma hayatının geleceği kitabı içinde (s. 125-171). Ankara: Gazi Kitabevi. 